\title{
Patterns of usage for English SIT, STAND, and LIE: A cognitively inspired exploration in corpus linguistics*
}

\author{
JOHN NEWMAN AND SALLY RICE
}

\section{Abstract}

Posture verbs with the meanings "sit", "stand", and "lie" are of considerable interest within cognitive linguistics on account of the richness of the polysemy and grammaticalizations that they enter into across languages. We explore the usage of English SIT, STAND, and LIE in over a dozen electronic corpora, relying primarily on the British National Corpus, a 100million word database of written and spoken language. The investigation reveals some interesting patterns of usage with these verbs which are reminiscent of the polysemy and grammaticalization facts associated with like items in other languages. Unlike some of their cross-linguistic correlates, the English cardinal posture verbs have not grammaticalized. Nevertheless, they are showing functional symptoms typically associated with the posture cohort in terms of frequency, collocational fixedness, tense/aspect-marking, and choice of participants, especially subject. Moreover, the actual constructional behavior of English SIT, STAND, and LIE gleaned from the corpora can be used to corroborate introspective and experimental evidence into their meaning and function in the language and suggest how these items may further develop in generations to come.

Keywords: corpus linguistics; posture verbs; grammaticalization; auxiliation; collocation; word association.

\section{Introduction}

Corpus linguistics, as a usage-based approach to the study of language, provides linguists with research tools which are particularly suited to the assumptions and goals familiar in cognitive linguistics. One familiar theme of the latter is that the grammatical patterns, constructions, and rules that linguists posit are abstracted from actual patterns of usage, 
rather than simply being the product of theorizing and model building. This leads to a usage-based understanding of grammar, whereby particular patterns and frequencies of co-occurrence typically associated with linguistic elements become relevant. Usage-based notions such as degree of familiarity, stochastic (if not sporadic) emergence, sanction of new usages, conventionalization, and entrenchment, as found, for example, in the works of Langacker (1987: 59-66, 1988, 1997) can all be investigated using the tools of corpus linguistics - indeed, it seems that such notions require these tools if one is to go beyond merely paying lip service to such concerns. Despite an obvious role for corpus linguistics in cognitive linguistics, reliance on corpora in support of claims about the polysemy of lexical items and constructions has not been especially widespread (see, however, Barlow and Kemmer 2000; Koops 2001, in press; Gries and Stefanowitsch 2002; Rice and Newman 2002). Indeed, this can be seen as a contradictory aspect in the practice of cognitive linguistics (cf. Schönefeld 1999: 165). In what follows, we describe a corpus-based investigation undertaken in the context of determining the actual usage and possible usage potential of three English posture verbs. The posture verbs we have in mind are the ones relating to the key at-rest positions: SIT, STAND, and LIE. ${ }^{1}$ We refer to these three lemmas as the cardinal posture verbs (CPVs).

Posture verbs hold a particular fascination for linguists because, in many languages, they enter into constructions which seem to have very little to do with either the static configuration of a theme or its dynamic positioning. Indeed, posture predicates routinely desemanticize in order to express more functional relations having to do with existence, location, tense/aspect, voice, deixis, classification, and social status (cf. Newman 2001, 2002a, 2002b). ${ }^{2}$ By way of illustration, consider the following examples from a variety of languages wherein cardinal posture verbs are categorically not being used to indicate posture or positioning:

$$
\begin{aligned}
& \text { a. j6e mu-tàju } \\
& \text { dance 1sG-sit } \\
& \text { 'I was dancing.' (Mamvu; Vorbichler 1971: 248-250) } \\
& \text { b. (à) 'dùwò-tó shír-mái } \\
& \text { (3SG) sit-3sG.F steal }
\end{aligned}
$$

'She habitually steals.' (Kanakuru; Newman and Schuh 1974: 35)

$\begin{array}{lllll}\text { (2) a. } & \text { stava } & \text { per perdere il } & \text { treno } \\ & \text { stand.3SG } & \text { PREP } & \text { lose.INF } & \text { DEF.M train }\end{array}$ 'He was about to miss the train.' (Italian; Devoto and Oli 1971: 2347) 
b. ' $h$ '.n rdj.n.f $n \quad$ (.j) $n n$

stand.PaST give.PaSt.3.M for/to $1 \mathrm{SG}$ this

'Thereupon, he gave me this.' (Middle Egyptian; Gardiner 1957: 391-392)
a. x-ma'hta'ha'lh-má:lh pán $x n i^{\prime}$
PAST-guard-lie pig

'He took care of the pigs.' (Upper Necaxa Totonac; David Beck, p.c.)

b. i-pile-la-be i-eno

3sG.REALIS-speak-LIMITER-and 3sG.REALIS-lie

'He kept talking.' (Manam; Lichtenberk 2002: 280)

In (1a), the sIT morpheme functions as a past progressive aspect marker; in (1b), as a habitual. Clearly, both focused activities (dancing and stealing) transpire in the absence of sitting. In (2a), the STAND morpheme indicates ingressive aspect, while in (2b) it functions impersonally and pragmatically as a consecutive conjunction. In (3a), the LIE morpheme marks progressivity (the basic postural sense is unequivocally impossible), and in (3b), persistence. These examples illustrate the extent to which cardinal posture verbs can grammaticalize cross-linguistically. Habituality and progressivity frequently develop out of basic postural senses. No doubt these auxiliarized aspectual functions originally extended from the main verb senses in contexts where some action was being expressed while the subject was sitting, standing, or lying. Gradually, these postural connotations have weakened in these languages to the point that any activity can be extended aspectually via posture-based auxiliaries (cf. Kuteva 1999).

There are other compelling properties associated with posture verbs cross-linguistically which call out for some sort of cognitive-based analysis. By this we mean, of course, an analysis expressly concerned with usage, experientialist semantics, and discourse function. In English, the cardinal posture verbs are compelling from a cognitive perspective because they are fairly polysemous and syntactically divergent. The polysemy includes action and state senses of posture (e.g., She quickly sat (down) on the chair vs. She was sitting (down) for a long time), copulalike uses (e.g., to sit tight, to stand firm, to lie fallow), locational senses (e.g., The house stood on the corner, The property lies between two roads), and a range of miscellaneous extensions (e.g., to stand for something else, to stand for election, to stand up to someone, to stand someone up ('to not keep an appointment'), to sit an examination, to sit on a project ('to not take action on it'), to lie in ruins, to lie in wait). Despite this range of usage, the English cardinal posture verbs have not undergone any appre- 
ciable grammaticalization as of yet. Their uses as locational predicates or as copula-like verbs are relatively restricted and have not progressed to the stage of grammaticalization and change of grammatical category that can be observed in many other languages. It is certainly not our purpose here to argue that the posture verbs in English have grammaticalized along the lines of the examples in (1) to (3) above and inter alia below. Nevertheless, the patterns of usage that these verbs exhibit in English are revealing in the way they establish linguistic relationships which are pertinent to the discussion about grammaticalization and to our understanding of the behavior of basic verbs.

Quantitative studies, such as those which identify frequencies of morphemes and constructions, are essential to discussions of grammaticalization, even though no claim is made that high frequency of occurrence, by itself, is sufficient to explain the grammatical extension undergone by a lexical item or morpheme. ${ }^{3}$ Furthermore, grammaticalization is seen by many researchers as change which originates in, and finds its explanation in, usage. Bybee, Perkins, and Pagliuca (1994: 297), for example, observe that "it is the use of language in context that shapes the meaning of grammatical morphemes". We concur with this view that grammaticalization occurs in constructions and will, in the following sections, provide collocations with English cardinal posture verbs which strike us as ripe for potential grammatical extension. Indeed, it is the theme of Bybee and Hopper (2001) that grammaticizing constructions undergo extreme increases in frequency. The English cardinal posture verbs have clearly not yet reached a critical frequency threshold which might trigger (a) desemanticization of meaning or (b) generalization of distribution - key indicators of grammaticalization. Moreover, the units of a grammaticizing construction often reduce and fuse together as the expressive sequence comes to be processed as a single lexical item or precompiled phrase. This, too, has not yet happened to the English cardinal posture verbs. While there are often commonalities among the three cardinal posture verbs, the semantic and usage differences among them are real and any study of these verbs must necessarily respect these differences. In our study we pay particular attention to these distributional differences in the corpus and how such facts bear on questions of their potential grammaticalization.

\section{Posture verbs and cognitive linguistics}

Posture verbs and the polysemy they enter into have been the focus of a number of cognitively oriented or at least cognitively compatible studies, such as van Oosten (1982); Gibbs, Beitel, Harrington, and Sanders 
(1994); Serra Borneto (1996); Kuteva (1999); and Newman (2001). Sit and LIE are especially polysemous cross-linguistically, entering as they do into a fairly standard set of experientially based implicatures which have developed into some common context-independent senses. Frequently, SIT morphemes also mean "stay" and "live", while LIE commonly means "rest" or "sleep" as well as "lie". "Stand" verbs are also liable to take on (somewhat less predictable) semantic extensions and this is true of English STAND. ${ }^{4}$

The grammaticalization processes affecting posture verbs have been discussed in various publications of interest to cognitive linguists (cf. Austin 1998; Comrie 1976: 102; Bybee et al. 1994: 131-132; Early 1995; Heine et al. 1991: 117-118; Heine 1994: 270-271; Kuteva 1999; Newman 2002b, and the chapters therein, especially Newman 2002a; Watkins 1976). Based on Heine and coauthors (1993), we list in (4) some of the grammaticalized extensions typically associated with these verbs crosslinguistically (some of which are illustrated in examples [1] to [3] above). ${ }^{5}$ The extensions listed in (4) by no means exhaust all the grammaticalization possibilities of these verbs, but they provide a convenient overview based on the findings of one extensive study.

(4) a. SIT > progressive marker; present marker; habitual marker; copula; locative marker IN; locative marker NEAR; concessive marker; counter-expectation marker NOT YET

b. STAND [stative verb] > progressive marker; durative marker; present marker; ingressive marker; copula; distributive

c. STAND [verb of motion] $>$ consecutive clause marker

d. LIE (DOWN) [stative verb] > habitual marker; progressive marker

Grammaticalized extensions such as those in (4) may co-exist in varying degrees with the original posture meanings. One common instance of this gradualness of extension concerns the use of a posture verb to indicate the location or existence of an entity rather than the posture it assumes as such. In a sentence such as Kim was sitting on the sofa, the verb sit simultaneously describes a kind of posture as well as where Kim is located with respect to some reference point, the sofa. The simultaneous presence of both a posture sense and a locational function is a common feature of these predicates in English, with the context of use determining which sense is communicatively more relevant, hence, profiled. In English, the locational use is relatively undeveloped, a point we return to in section 6. However, in other languages location is a prominent feature of SIT, STAND, and LIE verbs, as in Dutch (cf. van Oosten 1982), German (cf. Serra Borneto 1996), and, indeed, in a host of other languages as well (see the chapters in Newman 2002b). 
The grammaticalization chains underlying the extensions in (4) may puzzle researchers interested in the motivations and stages by which such changes take place. For some languages we may have a written record of intermediate diachronic stages relevant to the grammaticalization, as in the case of the extension of "stand" to progressive or durative kinds of aspectual marking in some Romance languages. More often as not, however, such historical documentation is lacking and we are simply presented with grammaticalization as a fait accompli, requiring us to establish more indirect lines of argumentation for particular paths and time-courses of evolution. Cross-linguistic comparisons can profitably be used to help plot plausible extensions when relevant historical facts are lacking for a particular language. In this sense, a study of English cardinal posture verbs may yield results which illuminate the grammaticalizations of counterpart verbs in other languages and, indeed, we believe the present study does just this.

Earlier research on the extensions of posture verbs cross-linguistically form the backdrop to the present study. It suggests directions for us to follow in exploring patterns of usage exhibited by these verbs in English corpora. Our aim is not to argue for formerly unattested grammaticalizations of these verbs in English (primarily because these verbs are not yet on the verge of grammaticalizing), but rather to identify patterns of occurrence and co-occurrence which are congruent with the facts observed about the grammaticalization of this verb class, like those listed in (4) and exemplified earlier in (1) to (3).

Many of the conceptual associations which intrigue cognitive linguists and which are the subject of discussion in the cognitive linguistics literature are those that have their motivation in a specific context of usage. It is common to acknowledge the role of context in explaining a range of linguistic phenomena. Context can be taken to be linguistic or extralinguistic, and indeed reference to context is sometimes vague as to which kind of context is intended. What we attempt here is an operationalization of this idea of context. We have tracked both the lexical collocates and the grammatical marking manifested by English cardinal posture verbs in thousands of usage contexts extracted from a variety of electronic corpora. This has allowed us to chart both expressive range and frequency of usage as we try to link linguistic items and constructions to their conceptual underpinnings as well as to their pragmatic deployment. Perhaps the most striking initial finding is that the English cardinal posture verbs differ greatly in their overall frequency of usage. If frequency is indeed an early indicator of susceptibility to grammaticalization, then the English cardinal posture verbs are not likely all on the same trajectory. As will be shown, SIT far outpasses the other two cardinal posture verbs in 
its relative frequency, but more importantly, it outranges the others in its collocational diversity. We turn to this point in the next two sections.

\section{Relative frequency of posture verbs in the BROWN corpus using WordNet}

SiT, STAND, and LIE verbs are sometimes referred to collectively as "posture verbs" or "position verbs". The commonality between the verbs, as suggested by such terms, should not be taken to mean that the three verbs are directly comparable in their semantic scope or syntactic application. In this regard, our initial queries centered on the actual use of the English lemmas SIT, STAND, and LIE when these verbs are used to describe the static posture or dynamic positioning of animates as in Lee was standing next to the chair, Lee often sits on this sofa, Lee likes to lie down on this sofa.

Of course, there are many uses of these forms which are irrelevant to the present discussion and these errant senses must be identified and removed from the database. The most obvious intrusion of unwanted uses concerns the "tell a lie" senses found with lie(s) and lying. In addition, the past tense lay is identical to some forms of the transitive verb lay. Both stand and lie are used as nouns in English (take a stand on something, the lay of the land, tell a lie) whereas the focus of this study is on posture verbs, not nouns. Finding ways to exclude some or all of the unwanted uses is a familiar methodological problem in corpus linguistics. Ideally, one would like a corpus which has been parsed and analyzed to such a degree of detail that one can simply search for a lemma such as SIT 'to be in a seated position', as opposed to a form sit. In fact, this has been done as an application of the WordNet project for parts of the BROWN corpus (its attributes are described in Table 3). The documentation accompanying WordNet provides statistics on the frequency of lemmas restricted to a particular meaning in this corpus (Fellbaum 1998). It should be noted that the tagging applied to the BROWN corpus was done manually. It is one thing to distinguish the various senses of a form in a dictionary; it is quite another to make a decision about which particular sense is present in a usage. Such determination is not without its difficulties. In the case of lie, for example, the senses 'be located or situated somewhere; occupy a certain position' and 'be lying, be prostrate; be in a horizontal position' must be distinguished. These senses are not always easy to tease apart in actual usage. It is a matter of degree which of these two senses is more relevant.

To illustrate the relevance of WordNet to the present discussion, some frequency figures for the simple verbs SIT, STAND, and LIE, as used in spe- 
Table 1. Frequencies of the major posture verbs with specific senses in the semantically tagged files of the BROWN corpus

\begin{tabular}{lllllc}
\hline Verb & (Stative) sense & Total & Verb & (Dynamic) sense & Total \\
\hline SIT & 'be sitting' & 47 & SIT DOWN & 'take a seat' & 10 \\
STAND & 'be standing, be upright' & 43 & STAND UP & 'arise, get up' & 8 \\
LIE & 'be lying, be prostrate, be & 35 & LIE DOWN & 'assume a reclining & 1 \\
& in a horizontal position' & & & position' & \\
\hline
\end{tabular}

cific senses, are given in Table 1. The left-hand columns indicate the occurrence frequency of these verbs when used statively without any accompanying verb particle such as up, down, back, etc. The right-hand columns give frequency numbers for these verbs when they are used dynamically with the verb particles indicated. Both searches yield a not completely predictable result: SIT is marginally more frequent than STAND, and LIE is the least frequent posture verb of the set. The relative frequency of the cardinal posture verbs with respect to each other is of considerable interest, but we postpone discussion of this until the next section.

By comparison, consider the much smaller relative frequencies for a number of other, "non-cardinal" posture verbs in English shown in Table 2 , again based on the semantically tagged files of the BROWN corpus. In

Table 2. Frequencies of selected minor posture verbs in the semantically tagged files of the BROWN corpus

\begin{tabular}{|c|c|c|c|}
\hline Verb & Sense (both stative and dynamic) & Sample usage & Total \\
\hline HANG & 'be suspended or hanging' & The flag hung on the wall. & 12 \\
\hline LEAN & $\begin{array}{l}\text { 'incline or bend from a vertical } \\
\text { position' }\end{array}$ & She leaned over the banister. & 7 \\
\hline SQUAT & 'sit on one's heels' & $\begin{array}{l}\text { The women squatted by the river } \\
\text { on washday. }\end{array}$ & 5 \\
\hline KNEEL & 'rest one's weight on one's knees' & I found him kneeling in a back pew. & 2 \\
\hline LOUNGE & 'sit or recline comfortably' & $\begin{array}{l}\text { He was lounging on the sofa all } \\
\text { afternoon. }\end{array}$ & 2 \\
\hline CROUCH & 'sit on one's heels' & He crouched down behind the wall. & 2 \\
\hline STOOP & $\begin{array}{l}\text { 'bend one's back forward from } \\
\text { the waist on down' }\end{array}$ & $\begin{array}{l}\text { The young man stooped to pick up } \\
\text { the girl's purse. }\end{array}$ & 2 \\
\hline BEND & $\begin{array}{l}\text { 'bend one's back forward from } \\
\text { the waist on down' }\end{array}$ & $\begin{array}{l}\text { He bent down, a black cranelike } \\
\text { figure, and put his mouth to the } \\
\text { ground. }\end{array}$ & 1 \\
\hline PERCH & 'sit, as on a branch' & The birds perched high in the tree. & 1 \\
\hline SPRAWL & $\begin{array}{l}\text { 'sit or lie with one's limbs spread } \\
\text { out' }\end{array}$ & Six girls sprawled on one bed. & 1 \\
\hline
\end{tabular}


this search, these minor posture verbs are being used statively and dynamically.

Again, the numbers refers to tokens of the lemmas, i.e., all the inflected forms of the verb with the specific meaning indicated. SIT, STAND, and LIE, in their basic stative posture senses shown in Table 1, are clearly set apart from the posture verbs shown in Table 2 in terms of frequency of occurrence. The distinction lends support to our decision to regard SIT, STAND, and LIE as the cardinal posture verbs of English.

The distinctiveness of English SIT, STAND, and LIE vis-à-vis the other posture verbs has counterparts in grammaticalization tendencies in other languages. We cite three types of extension patterns below: (1) locationals/existentials, (2) aspect/tense marking, and (3) a noun classification system. First of all, it is often only the cardinal posture verbs that go on to function as locational and/or existential predicates in a language. In Mbay (Nilo-Saharan), locational, existential, and a number of other constructions typically involve one of the three verbs $n d i$ 'sit', dà 'stand' and tò 'lie' (see Keegan 2002 for details of usage). Mbay also has a set of adverbs translating as 'here' and 'there' which are derived from the three posture verbs: $n$ dìn for an object viewed as sitting, dàn for an object viewed as standing, and tèn for an object viewed as lying. These posturebased adverbs enter into a set of locative expressions equivalent to 'here is/are, there is/are ...', as illustrated in (5).
a. Wór lò-í lā ndìn.
glass of-you that sit.ADV
'Here is your glass.' (Mbay; Keegan 1997: 775-776)
b. Dèe kàá ń ndà- $\bar{m}$ lā đàn.
person very that hit-me that stand.ADV
'There is the very person who hit me.'
c. Bík̀̀ lò-í lā tèn.
pen of-you that lie.ADV
'Here is your pen.'

Secondly, in some languages it is the posture verbs and only the cardinal posture verbs that may be extended to tense/aspect markers. In Kxoé (Khoisan), the verbs meaning 'sit', 'stand', and 'lie' all reportedly function as present tense markers especially when referring to an action performed while sitting, standing, or lying respectively (Köhler 1962: 545, 1981: 530; Heine et al. 1993). The extended uses are summarized in (6) and illustrated in (7). The auxiliary morphemes, called variously suffixes and particles, are formed from the corresponding posture verbs, which are "defective", i.e., they do not conjugate and are only used in the present tense. 
(6) a. $\quad \neq n \check{\tilde{u}}$ ' 'sit' $\rightarrow-\neq n u \dot{e}$ 'present tense particle, in sitting position'6

b. té, tĭ 'stand, be' $\rightarrow-t \grave{e}$ 'present tense, in standing position'

c. //ö̌ 'lie, be lying' $\rightarrow-/ /$ ò 'present tense marker, habitual'

d. $\neq n \tilde{\tilde{u}} \tilde{\imath}$ 'sit' $\rightarrow-\dot{n}$ 'present tense particle, in sitting position or in general'

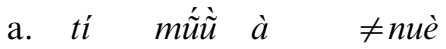
$1 \mathrm{SG}$ see PART sit
'I see (while sitting).'

b. tí mú̃ à̀ $a ̀$ tè

$1 \mathrm{SG}$ see PART stand

'I see (while standing).'

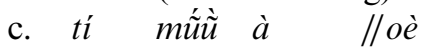

$1 \mathrm{SG}$ see PART lie

'I see (while lying).' (Kxoé; Köhler 1962: 545; Heine et al. 1993: 139)

Mbay uses its three posture verbs in a similar way, i.e., as auxiliaries indicating progressive aspect. The original posture sense is also present in some cases, but, as in Kxoé, the "sit" verb functions as a general progressive marker. So, for example, it is ndi 'sit' which is preferred as the progressive auxiliary with verbs of action and movement.

The third type of extension pattern exhibited by the cardinal posture verbs involves their redeployment as the basis of a classifier system. In Euchee (previously known as Yuchi; an Amerindian isolate, possibly Siouan), the morphemes $\breve{j} i$ 'sit, stay', $f a$ 'stand', and $P e$ 'lie' form the basis of a three-way 'gender' system (Wagner 1933-1938; Watkins 1976: 3536; Linn 2000). These same forms function as articles occurring with singular inanimate nouns, as shown in Table 3. Compare ya 'tree', but ya-fa 'the/this/that tree' (literally, 'tree-stand'). Animate nouns do not participate in this kind of classification. They are subclassified instead according to categories of tribal affiliation, kinship, and gender.

These examples from Mbay, Kxoé, and Euchee are just three illustrations of how the three cardinal posture verbs, which are so distinctive

Table 3. Posture-based Euchee articles (cf. Watkins 1976: 35-36, Wagner 1933-1938: 321322)

\begin{tabular}{|c|c|c|}
\hline$-\breve{i} i$ SIT class & $-f a$ STAND class & $-P e$ LIE class \\
\hline Example: tiǰi 'the rock' & Example: & Example: ya?e 'the log' \\
\hline $\begin{array}{l}\text { Also used in 'the chair', 'my } \\
\text { strength', 'my heart' }\end{array}$ & $\begin{array}{l}\text { Also used in 'the house', 'my } \\
\text { spirit', 'my eye' }\end{array}$ & $\begin{array}{l}\text { Also used in 'the field', 'the } \\
\text { rain', 'their language' }\end{array}$ \\
\hline
\end{tabular}


in their relative high frequency in English vis-à-vis other posture verbs, may also be distinctive, as a set, in their grammaticalizations in other languages. All of these grammaticalization facts reflect the cardinality of "sit", "stand", and "lie" as opposed to "crouch", "kneel", "lean", etc., a cardinality that can be detected in English through frequency counts in both written and spoken corpora. Presumably, a factor motivating all these phenomena is the relative salience of sitting, standing, and lying in our consciousness of human at-rest positions. Claims about the relative salience of some parts of our experience versus other parts are admittedly not easily substantiated in objectively quantifiable ways. However, the easily accessible and quantifiable corpus facts we are establishing for English could be taken as linguistic correlates of experiential embodiment.

\section{Relative frequency of the cardinal posture verbs in other corpora}

\subsection{Other corpora}

As useful as the semantically tagged BROWN corpus is, one must nevertheless go beyond this database in order to substantiate the results given in section 3 and to search for patterns only evident in much larger corpora. ${ }^{7}$ Therefore, in a more extensive set of searches, we made use of the eight corpora of written English listed in Table 4 and the five corpora based on transcriptions of spoken English listed in Table 5.

Of the written corpora we accessed in our study, the British National Corpus was by far the most impressive in terms of its size and, consequently, it was the corpus that we relied on most. The 100-million-word

Table 4. Names and attributes of the 8 written or predominately written English-language corpora used in this study

\begin{tabular}{|c|c|c|c|c|}
\hline Abbreviation & Title & $\begin{array}{l}\text { Variety of } \\
\text { English }\end{array}$ & $\begin{array}{l}\text { Size (in millions } \\
\text { of words) }\end{array}$ & $\begin{array}{l}\text { Time-frame } \\
\text { of sample }\end{array}$ \\
\hline $\mathrm{BNC}(\mathrm{w})$ & $\begin{array}{l}\text { British National } \\
\text { Corpus (written) }\end{array}$ & British & 90 & $1970 \mathrm{~s}-1990 \mathrm{~s}$ \\
\hline LOB & $\begin{array}{l}\text { London-Oslo- } \\
\text { Bergen Corpus }\end{array}$ & British & 1 & $1960 \mathrm{~s}$ \\
\hline FLOB & Freiburg-LOB & British & 1 & $1990 \mathrm{~s}$ \\
\hline BROWN & Brown Corpus & American & 1 & $1960 \mathrm{~s}$ \\
\hline FROWN & Freiburg-Brown & American & 1 & $1990 \mathrm{~s}$ \\
\hline $\mathrm{ACE}$ & $\begin{array}{l}\text { Australian Corpus } \\
\text { of English }\end{array}$ & Australian & 1 & $1980 \mathrm{~s}$ \\
\hline $\mathrm{WC}$ & Wellington Corpus & New Zealand & 1 & $1986-1990$ \\
\hline KOL & Kolhapur Corpus & Indian & 0.9 & 1978 \\
\hline
\end{tabular}


Table 5. Name and attributes of the 5 spoken English-language corpora used in this study

\begin{tabular}{|c|c|c|c|c|}
\hline Abbreviation & Title & $\begin{array}{l}\text { Variety of } \\
\text { English }\end{array}$ & $\begin{array}{l}\text { Size (in millions } \\
\text { of words) }\end{array}$ & $\begin{array}{l}\text { Time-frame } \\
\text { of sample }\end{array}$ \\
\hline $\mathrm{BNC}(\mathrm{s})$ & $\begin{array}{l}\text { British National } \\
\text { Corpus (spoken) }\end{array}$ & British & 10 & $1970 s-1990 s$ \\
\hline LLC & London-Lund Corpus & British & 0.5 & $1950 s-1980 s$ \\
\hline COLT & $\begin{array}{l}\text { Corpus of London } \\
\text { Teenage Lang. }\end{array}$ & British & 0.5 & 1993 \\
\hline WSC & $\begin{array}{l}\text { Wellington Spoken } \\
\text { Corpus }\end{array}$ & New Zealand & 1 & 1988-1994 \\
\hline SPAE & $\begin{array}{l}\text { Spoken Professional } \\
\text { Amer. Eng. }\end{array}$ & American & 2 & 1978 \\
\hline
\end{tabular}

British National Corpus consists of ninety percent written subcorpora and ten percent spoken. The remaining written corpora, distributed as part of the ICAME package of corpora, are comparable in so far as they all follow roughly similar principles in their selection of texts, with the BROWN and LOB corpora providing the early models. The spoken corpora taken from the ICAME set (LLC, COLT, WSC) and the SPAE are more diverse in their selection of material, as suggested by the titles of the corpora.

With WordNet (available for the BROWN corpus only) we have a simple and effective means of searching for forms with specific meanings, though one is limited to texts which have been tagged in this way. The fine-grained searching which can be invoked with WordNet is not available for other corpora (which is to say, the other corpora have not been manually tagged for particular senses of words) and we must find other means to exclude unwanted forms and meanings as we search for items and establish relative frequencies. As a way of identifying cardinal posture-verb forms which are primarily about posture or position (as opposed to figurative uses), we searched the twelve corpora listed for the cardinal posture-verb lemmas as they occur in the phrasal combinations SIT DOWN, STAND UP, LIE DOWN. The occurrence of these items by corpus is given in Tables 6 and 7. The addition of the verb particle excludes a large number of the unwanted senses of SIT, STAND, and LIE. It largely excludes, for example, the "tell a lie" sense of LIE and many of the locational senses of SIT with inanimate subjects (cf. The car is sitting in the garage vs. *The car is sitting down). Even so, the search strings permitted some intrusion of unwanted senses: the form lay down could be a transitive verb form; STAND UP can occur with a figurative, non-postural 
Table 6. Normalized frequency per million words of SIT DOWN, STAND UP, LIE DOWN in the written corpora (actual frequencies in parentheses where the corpus is not 1 million words)

\begin{tabular}{llll}
\hline & SIT DOWN & STAND UP & LIE DOWN \\
\hline BNC (w) & $45.3(4,084)$ & $35(3,150)$ & $13.1(1,185)$ \\
LOB & 60 & 29 & 10 \\
FLOB & 44 & 30 & 8 \\
BROWN & 46 & 42 & 6 \\
FROWN & 41 & 27 & 13 \\
ACE & 35 & 29 & 12 \\
WC & 45 & 34 & 17 \\
KOL & $46(41)$ & $21(19)$ & $20(18)$ \\
\hline
\end{tabular}

meaning as in she should stand up to her boss, etc. These were relatively rare, but they do slightly inflate the figures for STAND UP and LIE DOWN.

It can clearly be seen in Tables 6 and 7 that the relative order of frequency across all twelve corpora for the three target expressions is SIT DOWN $>$ STAND UP $>$ LIE DOWN. Indeed this relative frequency is evident in every one of the corpora we searched. This is a striking result. Admittedly, in the compilation of the LOB, FLOB, BROWN, FROWN, $\mathrm{ACE}, \mathrm{WC}$, and KOL corpora, there was an attempt to follow a similar procedure in terms of size and coverage of genres. Consequently, the similarity in frequencies of the cardinal posture verbs in these corpora is perhaps not so surprising. However, the British National Corpus was compiled in a somewhat different manner and the spoken corpora are each quite distinct in their approach to collection of data and the nature of the speech recorded. The convergence of results, including these more idiosyncratic corpora, is therefore noteworthy.

These frequency distributions could be seen as a reflection of the relative roles that the cardinal postures play in our daily lives. Sitting and

Table 7. Normalized frequency per million words of SIT DOWN, STAND UP, LIE DOWN in the spoken corpora (actual frequencies in parentheses where the corpus is not 1 million words)

\begin{tabular}{lclc}
\hline & SIT DOWN & STAND UP & LIE DOWN \\
\hline BNC (s) & $80.9(809)$ & $35.9(359)$ & $16.5(165)$ \\
LLC & $42(21)$ & $26(13)$ & $4(2)$ \\
COLT & $144(72)$ & $28(14)$ & $18(9)$ \\
WSC & 66 & 43 & 17 \\
SPAE & $39(78)$ & $17(34)$ & $1(2)$ \\
\hline
\end{tabular}


standing are postures we typically assume many times a day, whereas lying is a posture that, for most people, is associated only with unconscious sleep. Sitting and standing, to some extent, occur as parts of the same episode: we sit down (or stand up) in order to do something else and when that activity is finished we stand up (or sit down) again. In terms of maintaining postures, sitting is the most comfortable position in our daily life and the one that lends itself most to socializing, reflection, and prolonged occupation with some other activity. Standing becomes quickly uncomfortable in comparison with sitting. In terms of both entering the posture, maintaining the posture, and purposefulness of the posture, it would appear that sitting is the most salient. The results from all the corpora we searched indicate that SIT is the most frequent of the cardinal posture verbs, reflecting a (vague) intuition that sitting is privileged experientially and linguistically.

Higher frequency is a feature of grammatical (including grammaticalized) morphemes of a language (cf. Bybee et al. 1994: 4-9; Bybee and Hopper 2001), and so the higher frequencies of SIT and STAND meanings that we have observed would favor these morphemes developing into grammaticalized morphemes rather than LIE. Higher frequency by itself, of course, does not cause a morpheme to grammaticalize, but it would presumably facilitate grammaticalization since along with increased frequency usually comes more generalized usage. Admittedly, raw frequency of isolated morphemes does not tell the whole story. Recent quantitative work by Gries and Stefanowitsch (2002) and Deane (2002) attests to the import of looking at the relative frequencies of multiple-word sequences in a language in order to determine a particular sequence's susceptibility to conventionalization as a construction. Such conventionalization would surely be a necessary first step along the path towards grammaticalization. Gries and Stefanowitsch have coined the term collostruction to characterize the idea of collocational strength or the advent of constructions (e.g., DITRANSITIVES, RESUltatives) from highly frequent collocations with particular verbs (e.g., give, make) as well as the idea of constructional faithfulness or the restriction of certain rarer verbs (e.g., award, render) to particular constructional contexts. In a similar but independently motivated vein, Deane has provided evidence that Zipf's (1932) first law - that the frequency of a linguistic category tends to be inversely proportional to its rank in a frequency distribution-applies to constructions as well as to words. Deane has examined bigram and trigram frequencies for a number of verbs in English and in so doing has determined the relative frequency of verbs within a particular construction (e.g., DITRANSITIVES [give me a], AFFECTED PART CONSTRUCTIONS [hit him on the]). The upshot of both studies is that constructions can emerge 
(or be acquired by children) from the collocational behavior of a very small set of frequently occurring verbs. In turn, the resulting constructions inherit particular implicatures based, in part, on the verbs with which they are most likely to be associated. This is consistent with Hopper's (1991: 22) Principle of Persistence:

When a form undergoes grammaticalization from a lexical to a grammatical function, so long as it is grammatically viable some traces of its original lexical meanings tend to adhere to it, and details of its lexical history may be reflected in constraints on its grammatical distribution. ${ }^{8}$

In the present study, we argue for a kind of interaction between lemma (one of the cardinal posture verbs) and construction type comparable to those noted by Gries and Stefanowitsch (2002) and Deane (2002). Some of the resulting collocations we examine below (e.g., sit around and) are consistently imbued with semantic and pragmatic properties that have clearly conventionalized and may eventually grammaticalize. Thus, while there may be some correlation between a morpheme's frequency and its potential for grammaticalization, other factors play a part. In particular, facts relating to the occurrence of the morpheme in actual contexts with particular collocates need to be considered. This leads to a more detailed investigation of the cardinal posture verbs and their collocations and we turn to phrasal patterns in the next section.

\section{Collocates of cardinal posture verbs in the British National Corpus}

In addition to establishing absolute frequency distribution facts for the English cardinal posture verbs, we investigated selected collocational patterns with them in the hope of revealing more information about the use and usage potential of these verbs. In particular, we were interested in determining the range of verbal predicates which had a close association, in terms of their usage and constructional co-occurrence, with the posture verbs in a corpus. The British National Corpus was selected for this purpose both because of its size and because it samples both written and spoken forms of English.

As one way of operationalizing "close association", we searched for instances of the posture verbs occurring as the first conjunct in a conjunction of verbs with and. We distinguished two different searches along these lines:

(8) a. sitting/standing/lying and ... V-ing

b. sat down/stood up/lay down and ... V-ed 
The -ing forms in (8a) are typically present participles while the (8b) forms involve either past tense or past participial forms. The (a) cases correspond semantically to simultaneous conjunction, i.e., the conjunction refers to a stative posture and the actions/states of the person(s) while in that posture. Another interesting subcategory of simultaneous conjunction involving posture verbs is the "SIT/STAND/LIE around and V"-frame which is associated with quite special semantic effects and so we explore instances of this subcategory as well. The (8b) forms correspond to consecutive conjunction, referring typically to the dynamic action of entering a posture and the actions/states which the person(s) engaged in afterwards. The second conjunct in each case immediately followed and. The search strings in (8) were not the only ones we used in our study, but these searches were particularly productive and insightful.

Our choice of simultaneous and consecutive conjunction as a focus for exploring collocates derives mainly from an intuition on our part that these particular syntactic frames could yield interesting results. However, there is an additional justification for selecting these frames. Kuteva (1999: 208) specifically identifies the coordinate structure with and-type morphemes as a "locus-for-change", facilitating the grammaticalization of posture verbs into aspectual markers. Indeed, in a number of languages, a morpheme meaning "and" is an integral part of aspectual constructions. Some cross-linguistic examples of these coordinated and aspectualized CPV-V constructions are given in (9).
a. Jeg sitter og snakker. I sit.1sG.PRES and talk.1sG.PRES 'I am talking.' (Norwegian; Kuteva 1999: 195, ex. 7)
b. Sedi sit.3SG.PRES.IMPF and REFL complain.3SG.PRES.IMPF

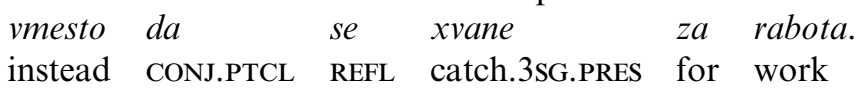 'He/she has been complaining all the time instead of starting to work.' (Bulgarian; Kuteva 1999: 191, ex. 1)
c. i-pile-la-be i-eno 3sG.REALIS-speak-LIMITER-and 3sG.REALIS-lie 'He kept talking.' (Manam; Lichtenberk 2002: 280)

Kuteva (1999) is concerned only with simultaneous conjunction involving cardinal posture verbs, the type of conjunction most closely associated with the development of locational or progressive kinds of aspectual meanings. As we shall see, consecutive conjunction with posture verbs is also a rewarding context to study, in terms of the somewhat aspectual- 
Table 8. Frequency of collocates of posture verbs in the simultaneous conjunction construction in the British National Corpus

\begin{tabular}{|c|c|c|c|c|c|c|c|c|}
\hline $\begin{array}{l}\text { Posture } \\
\text { frame }\end{array}$ & $\begin{array}{l}\text { Collocate } \\
\text { verb }\end{array}$ & Total & $\begin{array}{l}\text { Posture } \\
\text { frame }\end{array}$ & $\begin{array}{l}\text { Collocate } \\
\text { verb }\end{array}$ & Total & $\begin{array}{l}\text { Posture } \\
\text { frame }\end{array}$ & $\begin{array}{l}\text { Collocate } \\
\text { verb }\end{array}$ & Total \\
\hline $\begin{array}{l}\text { sitting } \\
\text { and }\end{array}$ & $\begin{array}{l}\text { watching } \\
\text { listening } \\
\text { waiting } \\
\text { looking } \\
\text { reading } \\
\text { thinking } \\
\text { talking } \\
\text { saying } \\
\text { staring }\end{array}$ & $\begin{array}{l}8 \\
6 \\
5 \\
4 \\
4 \\
4 \\
3 \\
2 \\
2\end{array}$ & $\begin{array}{l}\text { standing } \\
\text { and }\end{array}$ & $\begin{array}{l}\text { looking } \\
\text { staring } \\
\text { talking } \\
\text { balancing } \\
\text { bending }\end{array}$ & $\begin{array}{l}3 \\
3 \\
3 \\
2 \\
2\end{array}$ & $\begin{array}{l}\text { lying } \\
\text { and }\end{array}$ & $\begin{array}{l}\text { talking } \\
\text { waiting }\end{array}$ & $\begin{array}{l}1 \\
1\end{array}$ \\
\hline \multicolumn{2}{|c|}{$\begin{array}{l}\text { Subtotal collocates } \\
(\mathrm{N}>1) \\
\text { Other collocates } \\
(\mathrm{N}=1)\end{array}$} & $\begin{array}{l}38 \\
20\end{array}$ & $\begin{array}{l}\text { Subtotal } \\
(\mathrm{N}>1) \\
\text { Other co } \\
(\mathrm{N}=1)\end{array}$ & $\begin{array}{l}\text { collocates } \\
\text { locates }\end{array}$ & $\begin{array}{l}13 \\
31\end{array}$ & \multicolumn{2}{|c|}{$\begin{array}{l}\text { Subtotal collocates } \\
(\mathrm{N} \geq 1)\end{array}$} & 2 \\
\hline \multicolumn{2}{|c|}{ Total in corpus } & 58 & Total in & corpus & 44 & \multicolumn{2}{|c|}{ Total in corpus } & 2 \\
\hline
\end{tabular}

ized collocational patterns it reveals in English and the way these patterns relate to cardinal posture verb-based grammaticalizations in other languages.

\subsection{Simultaneous conjuncts}

Table 8 summarizes the results of a search for the simultaneous conjunction template indicated in (8a). The total number of occurrences for each search frame is given at the bottom of each column. It should be noted that most of the lying and V-ing occurrences referred to the "tell a falsehood" sense and these were discarded before listing the co-occurring Ving forms. The table shows all of the V-ing collocates for sitting and $\mathrm{V}$-ing and standing and $\mathrm{V}$-ing for which there are more than one token. In the case of lying and V-ing, there were just two V-ing collocates. Sitting and $\mathrm{V}$-ing is noteworthy for having both the largest number of co-occurring forms $(\mathrm{N}=58)$, as well as the largest number of recurring patterns (especially frequent are watching, listening, and waiting). The meanings represented in the three columns involve some semantic, if not lexical, overlap (talking appears in all three columns), although some verbs are more specifically associated with only one of the posture verbs. Recurring verbs which are restricted to collocation with sitting include the cognitive/ mental verbs (reading and thinking). Recurring verbs collocating with 
standing include verbs requiring physical control (balancing and bending). Verbs relating to perception, such as looking and staring, occur with either sitting or standing. These are collocations which have clear experiential motivation. We do not list in Table 8 the collocate verbs for sitting and $\mathrm{V}$-ing and standing and $\mathrm{V}$-ing which have only a single occurrence. While it would be instructive to examine those individual verbs, space prevents us from doing so.

As a further comment on the co-occurrence of posture verbs and other verbs in a simultaneous conjunction, note that the collocations typically involve a lexical unidirectionality: the posture verb is mentioned first and then the other verb (e.g., sitting up in bed reading), not the other way around (e.g., reading in bed sitting up). In order to investigate this further, we searched different orders of the 〈posture verb, collocate verb $\rangle$ in the British National Corpus, drawing the "collocate verb" examples from those established by our previous searches. We searched over a span of five words, taking the first verb mentioned as occupying the first position and observed the occurrences we report in Table 9. Typical instances with the posture verb in the first position, which is the dominant pattern and the one we take to reflect the basic order, are shown in (10); examples with the posture verb in second position, the less typical or alternate order, are shown in (11):

(10) Basic order
a. sitting up in bed reading
b. sitting quietly and thinking
c. sitting around and talking
d. while I was sitting watching
e. standing in the doorway talking

Table 9. Alternative orders of posture verb and collocating verb sharing the same subject within a five-word span in the British National Corpus

\begin{tabular}{|c|c|c|c|c|}
\hline Verb & Collocation (basic order) & Total & Collocation (alternate order) & Total \\
\hline \multirow[t]{4}{*}{ SIT } & sitting ... waiting & 82 & waiting ... sitting & 6 \\
\hline & sitting ... reading & 66 & reading ... sitting & 0 \\
\hline & sitting ... talking & 33 & talking ... sitting & 3 \\
\hline & sitting ... thinking & 31 & thinking ... sitting & 1 \\
\hline \multirow[t]{3}{*}{ STAND } & standing ... watching & 53 & watching ... standing & 3 \\
\hline & standing ... waiting & 45 & waiting ... standing & 6 \\
\hline & standing ... talking & 40 & talking ... standing & 3 \\
\hline \multirow[t]{2}{*}{ LIE } & lying ... waiting & 15 & waiting ... lying & 1 \\
\hline & lying ... thinking & 13 & thinking ... lying & 4 \\
\hline
\end{tabular}




\section{f. standing at the counter waiting \\ g. lying here thinking}

(11) Alternate order

a. talking with him; sitting with him

b. talking standing up

c. Lili was waiting outside, standing between their cases

d. the letter was waiting, lying in her pocket

The numbers in Table 9 were checked line-by-line for consistency of the syntactic construction, i.e., the co-occurring V-ing collocates were interpreted as sharing the same subject and being part of the same integrated event. Consequently, examples like those in (12) were not included:

a. thinking of him sitting on a toadstool

b. thinking about my spectacles lying on the desk

c. other fragments of this fresco show alternate standing and sitting celebrants

d. one moment he's standing and the next he's sitting

The posture verbs in examples such as (10a), sitting up in bed reading, function to locate an entity and then, as an elaboration, the entity is further described by the other verb. It is not the other way around; viz. the posture verb never serves to further elaborate an already described entity or activity. This is reminiscent of how posture verbs can be used as general locational predicates or reference-point expressions in other languages. English may not use its cardinal posture verbs very much to locate non-animates compared with Dutch or German, but the data above suggest they play a part in presenting, locating, and introducing referent objects to the reader/hearer as a prelude to describing them more fully.

The research results for these simultaneous conjuncts correspond to the realities about the functions our postures play in our everyday behavior. We watch, listen, read, think, etc., while we are sitting. We carry out fewer of these activities while standing. And in the lying position, we engage in an even more restricted range of collateral activities. In a sense, the British National Corpus provides us with a means of quantifying these habits. The frequencies of the recurring patterns we see in the corpora indirectly reflect the physical and conceptual realities about human postures. It is SIT which occurs most frequently in the simultaneous conjunction construction and LIE which occurs least frequently. Not only is SIT the most frequent of the three verbs, but it enjoys the greatest range of collocates. The presence of verbs referring to mental activity and cognition is particularly noteworthy, especially in the case of reading and thinking. Both reading and thinking are activities which typically occupy 
an extended time span, as opposed to being momentary activities. That is, these collocates of sitting and ... point to a relatively drawn-out span of time in which the sitting and the associated activity takes place. All three posture verbs collocate with waiting, a verb specifically indicating a prolonged period.

Standing and ... introduces verbs referring to particular types of muscular or sensorimotor control, such as bending and balancing, which do not occur with either of the other posture verbs as recurring patterns. The presence of these two verbs in the set of recurring collocates with standing and ... is especially interesting in that it mirrors one of the findings of Gibbs, Beitel, Harrington, and Sanders (1994) alluded to above. Gibbs and his co-researchers found that RESISTANCE, CENTER-PERIPHERY, BALANCE, VERTICALITY, and LINKAGE were the dominant image schemas that subjects identified in their conceptualization of standing. These two collocates (bending and balancing) would appear to very directly involve the notions of CENTER-PERIPHERY, BALANCE, and VERTICALITY. The collateral verbs looking and staring are common to both sitting and ... and standing and ..., but absent with lying and.... These simple co-occurrence patterns underscore the fact that, while lying down, an animate entity is not as likely to be alert cognitively, circumstantially able to see, and consequently engaged in perceptual activities as when sitting or standing. Table 10 summarizes some of the other distributional facts as well as the implicational values or connotations associated with the English cardinal posture verbs in simultaneous conjunction.

The collocational facts of English reveal conceptual associations comparable to the kinds of conceptual linkages that play a part in gramma-

Table 10. Attributes associated with the English cardinal posture verbs in the simultaneous conjunction construction

\begin{tabular}{ll}
\hline CPV collocation & Properties and associations \\
\hline sitting and ... V-ing & $\begin{array}{l}\text { has robust collocate inventory } \\
\text { collocates with verbs of MENTAL ACTIVITY, COGNITION } \\
\text { collocates with verbs of VISUAL and AUDITORY PERCEPTION } \\
\text { is most strongly associated with EXTENDED DURATION } \\
\text { has fewer collocates than sitting and ... } \\
\text { collocates with verbs of BALANCE, PHYSICAL EXERCISE } \\
\text { collocates with verbs of VISUAL PERCEPTION } \\
\text { is associated with EXTENDED DURATION } \\
\text { has least robust collocate inventory } \\
\text { is marked by absence of recurring patterns } \\
\text { is associated with EXTENDED DURATION }\end{array}$ \\
\hline
\end{tabular}


ticalizations in other languages. The British National Corpus collocations with verbs indicating events or states of extended duration can be seen as corresponding to the grammaticalization of cardinal posture verbs to aspectual markers indicating progressive, durative, continuative, or habitual (see section 2). The British National Corpus shows us that even in languages in which no auxiliation of the cardinal posture verbs has occurred, the aspectual meaning is inferrable from the semantics of their collocates. Our findings are consistent with Kuteva's (1999) proposal that simultaneous conjunction is a natural construction to look at for the development of an aspectual meaning. Our findings show English to be similar to languages such as Trumai (an isolate language of Brazil) in which the posture verbs have special uses as auxiliaries. In the case of Trumai, the "auxiliary" use of the posture verb indicates the posture that the subject is in while engaged in some other event, coded by the main verb (cf. Guirardello-Damian 2002). Guirardello-Damian argues that the Trumai posture verbs are auxiliaries in these constructions, citing the fact that they pattern just like other verb modifiers manifesting auxiliary properties. The Trumai auxiliation facts are discussed further in Guirardello (1999: chapter 4) and exemplified in (13) below:

$$
\begin{aligned}
& \text { a. Koinu-o wal la } \quad \text { ka_in. } \\
& \text { Koinu-ABS sing be.standing FOC/TENS } \\
& \text { 'Koinu while standing is singing.' (Trumai; Guirardello- } \\
& \text { Damian 2002: ex. 24) } \\
& \text { b. kiki yi otl tsula chïin. } \\
& \text { man yi sleep lie FOC/TENS } \\
& \text { 'The man was sleeping lying.' (Trumai; Guirardello-Damian } \\
& \text { 2002: ex. 31) }
\end{aligned}
$$

English allows a similar kind of integration of posture meaning and other state/activity meaning through conjunction (as well as the possibility of an omitted second subject). In both English and Trumai, the cardinal posture verb keeps its original posture sense but in Trumai there is evidence of its additional grammaticalization into an auxiliary. Our study of posture verbs in English corpora attempts to further elaborate and refine these claims about grammaticalization, especially in its earliest stages. Evidence of grammaticalization is lacking in English where the posture verbs retain their full verbal properties. Nevertheless, English boasts recurring patterns of V-ing collocations in the simultaneous conjunction construction where Trumai shows grammaticalization of verbs in sequence.

While our focus here is on potential roots of grammaticalization, it may be noted that some of the collocational patterns we observe in En- 
glish have parallels in lexicalizations in other languages. For example, Early (1995) mentions the use of the Lewo (oceanic) cardinal posture verbs with -mate 'wait', a morpheme that appears to occur only as a bound morpheme, and notes specifically the expressions to-mate 'sit-wait', su-mate 'stand-wait', and mo-mate 'lie-wait' as illustrations of its appearances in lexical items. This is reminiscent of some of the collocational patterns which can be observed in English, in particular, waiting as a recurring collocate of sitting ... as well as lying.... In Lewo, we see a fusing together of two verb forms as a single lexical item, corresponding to recurring phrasal patterns in English.

\subsection{Around constructions}

It is not only the conjunction of $\mathrm{V}$-ing forms where we see temporal overlap of activities and states. Another set of search strings which yielded comparable results involves the expressions SIT around and ..., STAND around and ..., and LIE around and.... The presence of around in these expressions accentuates the idea of a prolonged state, as well as hinting at futile, lazy, or otherwise unproductive activity. We searched the British National Corpus for these strings involving the lemmas of the posture verbs. The full set of hits from these searches is shown in the Appendix. There, we highlight by underlining only those second conjuncts where the overt or covert subject of the $\mathrm{V}$ is the same as that of the preceding posture verb (following the same procedure we used for the simultaneous conjunction construction). A comparison of the around expressions reveals that SIT around ... is the most common, while LIE around ... is unattested in the British National Corpus in the kind of use we are exploring (with an understood identical subject of the V-ing form following the conjunction). In Tables 11 and 12, we summarize a few properties of the collocate expressions returned in the SIT around and ... and STAND around and ... search strings exemplified in the Appendix.

These results mirror the returns from the previous set of searches based on sitting/standing/lying with respect to relative order of frequency. In cases such as sitting around and be depressed, sitting around and bitching, sitting around and waiting for inspiration, the actual posture or position of the person is not as salient for the overall meaning as the sense of drawnout inactivity. Some expressions may conjure up an image of individuals maintaining a particular posture, but note that a number of these do not. For example, in Yet actors here think they can just sit around and wait for jobs the reference is to some kind of lazy, inactive behavior directed towards not finding a job, rather than maintaining a seated position. Similarly, anybody who sits around and doesn't make the investment does not 
Table 11. Examples and attributes of the collocate expressions in the frame SIT around and in the British National Corpus (see Appendix for the full list)

\begin{tabular}{|c|c|c|c|}
\hline $\begin{array}{l}\text { Collocate } \\
\text { frame }\end{array}$ & Examples & $\begin{array}{l}\text { Semantic properties of } \\
\text { collocate expression }\end{array}$ & $\begin{array}{l}\text { Number of } \\
\text { occurrences }\end{array}$ \\
\hline \multirow[t]{5}{*}{$\begin{array}{l}\text { SIT around } \\
\text { and ... }\end{array}$} & $\begin{array}{l}\text { do nothing, not make, let } \\
\text { someone else, pray for a miracle, } \\
\text { grow old, sit around, wait for } \\
\text { something, watch } T V, \text { hope }\end{array}$ & expresses PASSIVITY & 16 \\
\hline & $\begin{array}{l}\text { talk, tell ghost stories, moan, } \\
\text { say, be asked, tell }\end{array}$ & $\begin{array}{l}\text { involves a COMMUNICATIVE } \\
\text { ACT }\end{array}$ & 10 \\
\hline & $\begin{array}{l}\text { have a drink, do a lot of eating, } \\
\text { have a meal, help themselves (to } \\
\text { food), sniff paint, vomit }\end{array}$ & $\begin{array}{l}\text { expresses CONSUMING/ } \\
\text { EXPELLING SOMETHING }\end{array}$ & 6 \\
\hline & $\begin{array}{l}\text { make some work, score, do } \\
\text { homework, write notes, pay bills, } \\
\text { think it over }\end{array}$ & involves a COGNITIVE ACT & 4 \\
\hline & $\begin{array}{l}\text { be depressed, bitch } \\
\text { listen }\end{array}$ & $\begin{array}{l}\text { expresses NEGATIVITY } \\
\text { involves a PERCEPTUAL ACT }\end{array}$ & $\begin{array}{l}2 \\
1\end{array}$ \\
\hline Total & & & 39 \\
\hline
\end{tabular}

necessarily refer to people maintaining a seated position; rather, it refers to waiting too long before (re)acting. Note also the use of just in some of the examples in the Appendix, repeated in (14). Just accentuates the inactivity, rather than emphasizing the seated position (or any other posture, for that matter). In fact, most English speakers would just as likely equally tolerate forms of SIT, STAND, or LIE following the word just in

Table 12. Examples and attributes of the collocate expressions in the frame STAND around and in the British National Corpus (see Appendix for the full list)

\begin{tabular}{|c|c|c|c|}
\hline Collocate fame & Examples & $\begin{array}{l}\text { Semantic properties of } \\
\text { collocate expression }\end{array}$ & $\begin{array}{l}\text { Number of } \\
\text { occurrences }\end{array}$ \\
\hline \multirow[t]{7}{*}{ STAND around and ... } & talk, laugh & involves a COMMUNICATIVE ACT & 3 \\
\hline & $\begin{array}{l}\text { listen, look at } \\
\text { something }\end{array}$ & involves a PERCEPTUAL ACT & 2 \\
\hline & not buy anything & expresses PASSIVITY & 1 \\
\hline & eat the provisions & expresses CONSUMING/ & 1 \\
\hline & & EXPELLING SOMETHING & \\
\hline & twitch & involves a PHYSICAL ACT & 1 \\
\hline & hate something & expresses NEGATIVITY & 1 \\
\hline \multicolumn{3}{|l|}{ Total } & 9 \\
\hline
\end{tabular}


these examples. This substitutability further suggests how diminished the postural meaning really is in these constructions with cardinal posture verbs. It is this kind of desemanticization that generally precedes fullblown grammaticalization of an expression in a language.

(14) a. You surely don't think I plan just to sit around and do nothing about getting my speedboat back, not to mention my cousin?

b. I enjoy talking about things other than golf, I love just sitting around and doing nothing, watching $T V$, going into the kitchen, walking around $a$ while and watching the stock market.

c. Yet actors here think they can just sit around and wait for jobs.

d. Do you just sit around and wait for inspiration?

e. Once you've been going to the same shops a lot, y'know, just standing around and not buying anything, they get to know you.

f. We'd been practising hard and were having a rest, just standing around and the Head Girl was smoking.

The verbs appearing as the second conjunct in the examples in the Appendix are also directly comparable to what was found above with sitting and $\mathrm{V}$-ing and standing and $\mathrm{V}$-ing. With sit around and ..., we find verbs referring to mental states such as think, pray, be depressed; with STAND around and ..., we find the perception verb look. Talk occurs with both. A number of the examples in the Appendix also suggest a certain uselessness or negativity such as sitting around and doing nothing. The inactivity is linked in such cases to a denigrating tone, which may be at least partially an effect of around, as noted in Rice and Newman (2002). This amounts to constructional polysemy such that a meaning of "extended inactivity" pragmatically shifts to a meaning of "extended inactivity of an undesirable kind". Note also the repetition in the case of I hate it when we sit around and sit around in the Appendix, again indicative of the emphasis on the prolonged nature of the state. The SIT/STAND around and ... part of these constructions is functioning, in variable degrees, as a "continuative" marker in the sense of Bybee, Perkins, and Pagliuca (1994: 127). That is, the posture verb is serving in part to indicate an action or state that persists for longer than normal because the agent is willfully prolonging it.

The situation with lie around and ... is a bit more complicated, but equally telling. In all cases with LIE AROUND extracted from the British National Corpus, the conjunction and truly introduces a new clause (with a different subject) rather than an elaborate simultaneous posture-verb collocation. In other words, LIE around and ... is not really a fixed "shared-subject" expression the way it seems to be (or becoming so) with SIT and STAND. Also, LIE around and more commonly occurs with inani- 
Table 13. Attributes associated with the English cardinal posture verbs in the simultaneous conjunction construction with around and in the British National Corpus

\begin{tabular}{ll}
\hline CPV collocation & Properties and associations \\
\hline SIT around and $\ldots$ & has relatively frequent and robust collocate inventory \\
& favors PROGRESSIVE marking \\
& suggests STATIVITY, PERSISTIVENESS, PASSIVITY, NEGATIVITY \\
prefers HUMAN subjects & takes collocates of social interaction \\
& favors PERFECTIVE marking \\
& suggests ACTIVITY, INTERACTIVITY \\
STAND around and ... & prefers HUMAN subjects \\
& no trends observed in collocate inventory beyond collocate \\
& having non-coreferential subject \\
& favors PROGRESSIVE marking \\
LIE around and ... & has weak EXISTENTIAL value \\
& prefers INANIMATE subjects \\
\end{tabular}

mate subjects (a pair of scissors, unexploded shells, the plates, etc.). Table 13 summarizes some of the more obvious properties associated with returns from the SIT/STAND/LIE around and searches (all of which are listed in the Appendix).

Why should LIE around and ... be exempt from the properties and associations we observe for the other two cardinal posture verbs? It could be that SIT/STAND and LIE are evolving an ecological complementarity such that the former are increasingly deployed with human subjects to reinforce an aspectually marked situation, while the latter is showing preference with inanimate subjects to reinforce existence and referential newness. In any case, a different set of patterns emerged when we examined expressions containing the English cardinal posture verbs in a consecutive conjunction construction. We turn to these next.

\subsection{Consecutive conjuncts}

The results of searching consecutive conjunction constructions containing the cardinal posture verbs, as shown in (8b), are summarized in Table 14. The relative frequencies of these three phrases in the British National Corpus are noteworthy, with stood up and ... clearly outnumbering the other two expressions, unlike the results obtained above for \{SIT DOWN, STAND UP, LIE DOWN\}, where SIT DOWN was far more frequent than the others. The reason for this difference may lie in a particular use that the sequence stood up and ... can be put to: the dynamic verb stand up can be, and often is, the beginning of further actions, particularly some kind 
Table 14. Frequency of collocates of posture verbs in consecutive conjunction construction in the British National Corpus

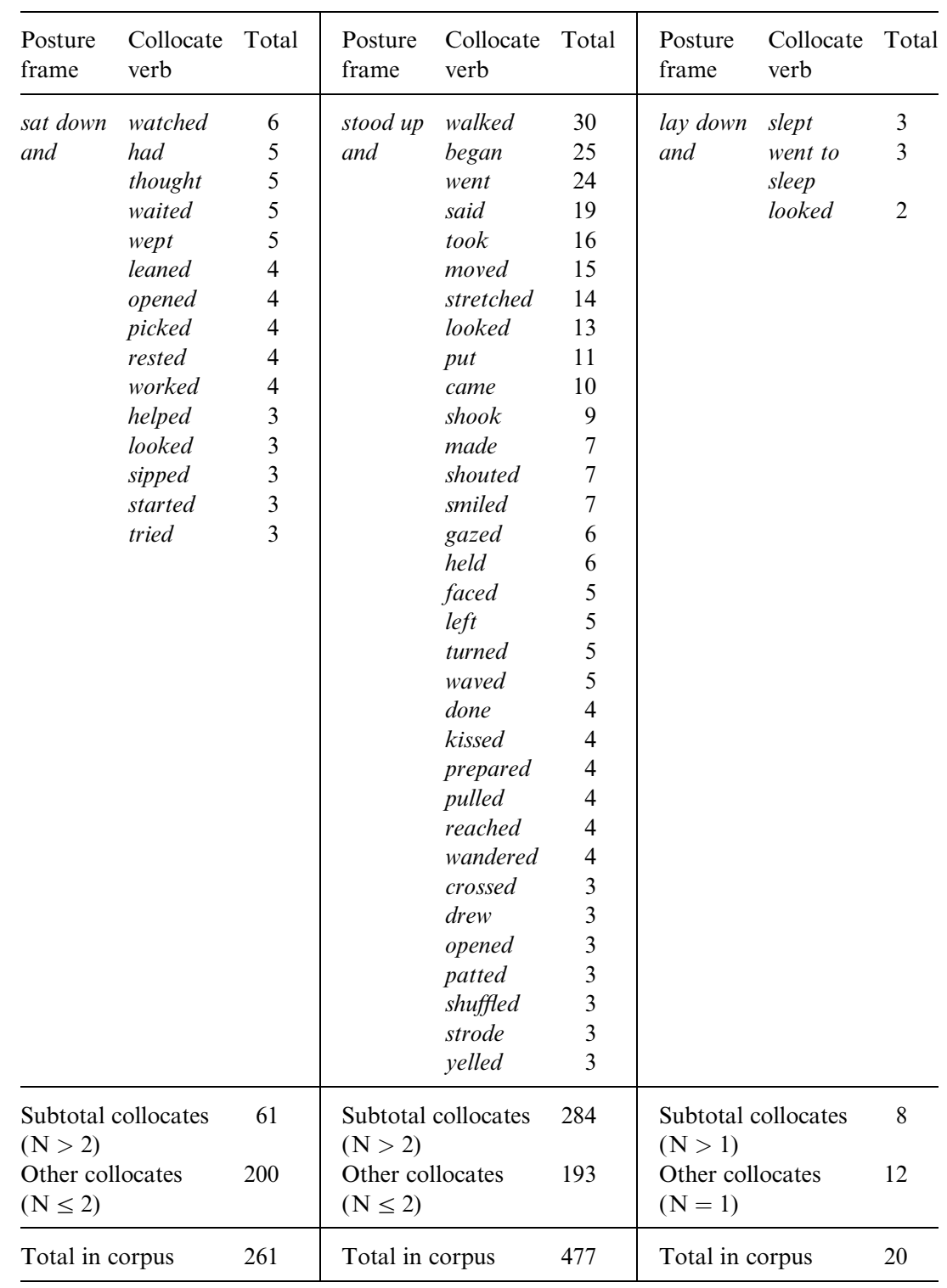


of motion. We see this inchoative function in the frequent occurrence of walked, went, moved, put, came, left, wandered, shuffled, and strode as second conjuncts in Table 14. No motion verb of this sort appears as a second conjunct after the other posture verbs. Went does appear after lay down and, but only in the expression went to sleep. The presence of so many of these motion verbs certainly contributes to the large number of stood up and V-ed occurrences, but this may not be the full explanation. In any case, standing up is a precursor to more subsequent actions, whether in a stationary position or moving, much more so than either sitting down or lying down is.

With the consecutive conjuncts, too, we see further body-based realities reflected in the corpus analysis. We often stand up in order to go somewhere, whereas we neither sit nor lie down in order to move elsewhere physically. One can, of course, sit down and immediately stand up again and walk away. However, in our normal everyday life, this is not a familiar set of actions. The results of our searches for sat down and ..., stood up and ..., and lay down and ... patterns are entirely consistent with these experiential observations. Only in the case of stood up and ... do we find the second conjunct ranging over actions which can be done while in a standing position as well as actions which predicate movement away from the standing position. Again, as humans we could just reflect on our own behaviors with respect to what we do on a daily basis after we sit down, stand up, and lie down and imagine what the typical scenarios might be and how they are routinely coded. The British National Corpus, however, provides us with a linguistic quantification of these intuitively held behavioral frequencies. Moreover, it gives us an empirical basis for positing probable chains of grammaticalization affecting the cardinal posture verbs. Table 15 summarizes the properties and associations which attach to the posture verbs in consecutive constructions.

Some grammaticalizations affecting STAND (UP) verbs in other languages appear to have evolved with the same set of properties typical of this cardinal posture verb in English as evidenced in the British National Corpus. For example, STAND verbs can be a source for the development of inchoative meanings. In Old High German, for instance, stantan 'stand' (a verb which could be used in the action sense of "enter into a standing state") could also mean "begin" (Schützeichel 1969: 182). "Stand" has also evolved into "become" verbs in a number of Slavic languages, e.g., Russian stat' 'become' (cf. Buck 1949: 636-637). Heine and coauthors (1993: 206) cite an example from Gardiner (1957: 391392) of a Middle Egyptian $h$ 'stand up, rise' used with a past-tense marker to form an auxiliary with the meaning "thereupon", indicating that there is a further action (this example has already been presented as [2b]). The 
Table 15. Attributes associated with the English cardinal posture verbs in consecutive conjunction construction in the British National Corpus

\begin{tabular}{ll}
\hline CPV collocation & Properties and associations \\
\hline sat down and ... & $\begin{array}{l}\text { presents smaller inventory of collocates than STAND } \\
\text { is associated with STATE or ACTIVITY IN A PLACE } \\
\text { prefers HUMAN SUBJECTS } \\
\text { presents most robust collocate inventory } \\
\text { is associated with STATE or ACTIVITY in a place } \\
\text { has INCHOATIV overtones } \\
\text { often serves as prelude to MOTION to another place } \\
\text { prefers HUMAN SUBJECTS } \\
\text { presents smallest inventory of collocates } \\
\text { is associated mainly with relatively PASSIVE STATES OR ACTIVITIES } \\
\text { prefers HUMAN SUBJECTS }\end{array}$ \\
\hline
\end{tabular}

British National Corpus gives us a glimpse into patterns with STAND in English, which, although not involving grammaticalizations, reveal contextual preferences which point in the same direction.

A search of the British National Corpus targeting the cardinal posture verbs immediately followed by still further illuminates this difference between STAND and SIT/LIE as well as the general tenet that constructions grammaticalize, not individual morphemes or lemmas. Still, in the postverbal position, typically has the meaning of "motionless", rather than the meaning of "continuing state or event" typical of the preverbal position (cf. She sat still there 'She sat there motionless' vs. She still sat there 'She continued to sit there'). As noted above, the sequential construction involving cardinal posture verbs revealed a clear collocational pattern of STAND (but not SIT or LIE) and motion verbs, reflecting the experiential realities of standing as a prelude to further action as compared to the other cardinal posture verbs. The collocation of the cardinal posture verbs with still reveals more about the experiential reality associated with these postures. The results of these searches involving still are shown in Table 16 (as a point of reference, compare the relative frequencies for these lemmas used statively in the BROWN corpus given in Table 1).

Table 16. Actual frequencies of SIT STILL, STAND STILL, and LIE STILL in the British National Corpus

\begin{tabular}{llll}
\hline & SIT STILL & STAND STILL & LIE STILL \\
\hline BNC & 170 & 512 & 186 \\
\hline
\end{tabular}


For the first time, we note a usage distribution that gives the frequency advantage to STAND over SIT and LIE. One way to understand this relative frequency is to recognize that sitting and lying have an inherent tendency to be relatively inactive states, compared with standing. Consequently, there is greater information value or noteworthiness associated with the collocation STAND STILL than with either SIT STILL or LIE STILL. The results of the still search provide a kind of independent evidence for the relative ratio of ACTIVITY : INACTIVITY or proprioceptive CONTROL : NONCONTROL that we associate with STAND vs. SIT/LIE, respectively.

In this section, we have compared the English cardinal posture verbs with regard to their co-occurrence with dynamic (especially motion) and stative verbs, negative implicatures, as well as different aspectual markers. The high or low frequency of cohort verbs, constructional frames, and other miscellaneous items in the corpora reflect most naturally how we intuitively associate postures and their collateral activities and how these associations are further assessed in discourse as unusual, worthy of mention, or otherwise informative. The usage properties of the English cardinal posture verbs at this level of detail are not readily available to introspection alone. Nevertheless, it is only at this level of detail that we begin to see these verbs evolving beyond their original lexical mandate of marking their subjects' physical configuration.

\section{Cardinal posture verb searches with the Edinburgh Associative Thesaurus}

We do not dismiss introspection as a research methodology in linguistics. When carried out with some degree of rigor and verifiability, it is a useful and expedient tool for linguistic analysis. The corpus-based approach adopted here should be viewed as complementary to any such experimentally or empirically based work in cognitive linguistics (cf. Rice 1996, 1999; Sandra and Rice 1995; Schönefeld 1999: 165-166). An example of rigorously applied introspection about linguistic representation, relevant to the English cardinal posture verbs, can be found in the Edinburgh Associative Thesaurus (EAT). This is a multitiered, psychologically based set of association norms for a smallish lexicon of English developed at the University of Edinburgh (cf. Kiss et al. 1973). ${ }^{10}$ It was compiled from an initial nucleus set of stimulus items taken from some well-known lexical network studies of English dating from the 1930s to the 1960s (viz. the 1,000 most frequent items in the Thorndike and Lorge [1954] count, Ogden's [1934] basic English vocabulary, and the 200 items from Palermo and Jenkins [1964]). This core set of items served as the stimuli for an iterated association task. Each item was presented to 100 
participants in a classroom setting, who in turn saw 100 randomized test items on an answer sheet. Their task was to write down as quickly as possible the first word which sprang to mind for each target item. The association responses from this first iteration were consequently given to a second set of participants who completed the same task. This cycle (using the output of each preceding experiment as input to the next) was repeated about three times until a set of approximately 8,400 stimulus words was reached. Associative norms were established for all items used as primes and responses. These items encompass a variety of lexical and phrasal forms, as well as a wide range of grammatical form classes and different inflected forms.

We enlisted the Edinburgh Associative Thesaurus in order to ascertain some association norms for the English cardinal posture verbs. These associations are telling insofar as they support explicitly some of the implicit properties and implicatures we observed from our earlier searches of the thirteen corpora used in our study. Table 17 lists the raw assocations returned from our query of the Edinburgh Associative Thesaurus, rankordered by frequency. The number alongside an associate in this table is the number of answers with this response out of a total of approximately 100 responses for each prompt word (100 responses for sit, 98 responses for stand, and 99 responses for lie). Immediately, one notices that the "tell a falsehood" sense of lie dominates the associates of lie and we isolated any associates obviously based on this sense and put them into a separate column in Table 17. In effect, then, we have just 36 total responses relevant to the posture sense of lie. A number of the stand associates (e.g., football, exhibition, grand, ice cream, music) presumably relate to the derived noun stand (grandstand, booth, kiosk).

For all three cardinal posture verbs, it is clear that the adverbs/verb particles $u p$ and down are significant as associates, reflecting the familiar verbal constructions STAND UP, SIT DOWN, and LIE DOWN (the same sequences that we chose as search strings in section 3). Clearly, these verbal constructions containing the adverb/particle have a certain prominence in the minds of speakers. Furthermore, each of the three cardinal posture verbs is associated with the other two, though not equally. Sit and stand stimulate each other as a response much more strongly than either stimulates the response lie. The dominance of the "tell a falsehood" sense of lie may play some part here, but it would not explain the deviation altogether. Thus, sit and stand stimulate each other as a response approximately as often as each stimulates the response of (sit) down and (stand) up, but lie stimulates sit and stand just once each, compared with 23 instances of (lie) down. The close association of sit and stand in the Edinburgh Associative Thesaurus is matched by the relative frequencies of 
Table 17. Associated items and association norms for the English cardinal posture verbs (probes) established through the Edinburgh Association Thesaurus

\begin{tabular}{|c|c|c|c|c|c|c|c|}
\hline \multirow{2}{*}{$\begin{array}{l}\text { sit } \\
\text { down }\end{array}$} & \multicolumn{3}{|c|}{ stand } & \multicolumn{2}{|c|}{ lie (posture sense) } & \multicolumn{2}{|c|}{$\begin{array}{l}\text { lie ("tell a } \\
\text { falsehood" sense) }\end{array}$} \\
\hline & 36 & sit & 30 & down & 23 & truth & 26 \\
\hline stand & 22 & $u p$ & 23 & bed & 2 & $f i b$ & 6 \\
\hline still & 8 & still & 8 & sleep & 2 & false & 5 \\
\hline chair & 7 & by & 4 & with & 2 & tell & 4 \\
\hline in & 6 & fall & 3 & couch & 1 & cheat & 2 \\
\hline lie & 3 & football & 3 & die & 1 & detector & 2 \\
\hline baby & 1 & hand & 2 & in bed & 1 & white & 2 \\
\hline boredom & 1 & upright & 2 & over & 1 & $a t$ & 1 \\
\hline command & 1 & aside & 1 & rest & 1 & don't & 1 \\
\hline crouch & 1 & band & 1 & sit & 1 & evil & 1 \\
\hline girl & 1 & behind & 1 & stand & 1 & forgive & 1 \\
\hline on & 1 & clear & 1 & & & guilt & 1 \\
\hline recline & 1 & erect & 1 & & & hate & 1 \\
\hline rest & 1 & erection & 1 & & & honest & 1 \\
\hline sat & 1 & ethics & 1 & & & little & 1 \\
\hline seat & 1 & exhibition & 1 & & & low & 1 \\
\hline strain & 1 & fairs & 1 & & & never & 1 \\
\hline think & 1 & fast & 1 & & & no & 1 \\
\hline tree & 1 & feet & 1 & & & not & 1 \\
\hline upon & 1 & grand & 1 & & & rather & 1 \\
\hline wait & 1 & halfway & 1 & & & tale & 1 \\
\hline well & 1 & ice cream & 1 & & & true & 1 \\
\hline where & 1 & lie & 1 & & & yes & 1 \\
\hline work & 1 & music & 1 & & & & \\
\hline & & obscene & 1 & & & & \\
\hline & & shout & 1 & & & & \\
\hline & & stay & 1 & & & & \\
\hline & & straight & 1 & & & & \\
\hline & & together & 1 & & & & \\
\hline & & wait & 1 & & & & \\
\hline & & waiting & 1 & & & & \\
\hline $\begin{array}{l}\text { Number of } \\
\text { different } \\
\text { associates }\end{array}$ & 24 & $\begin{array}{l}\text { Number of } \\
\text { different } \\
\text { associates }\end{array}$ & 31 & $\begin{array}{l}\text { Number of } \\
\text { different } \\
\text { associates }\end{array}$ & 11 & $\begin{array}{l}\text { Number of } \\
\text { different } \\
\text { associates }\end{array}$ & 23 \\
\hline
\end{tabular}

occurrence of SIT DOWN, STAND UP, and LIE DOWN in the corpora. Thus, in WordNet, SIT DOWN (10) > STAND UP (8) > LIE DOWN (1) (cf. section 3); in BNC(w) SIT DOWN $(4,084)>$ STAND UP $(3,150)>$ LIE DOWN $(1,185)$ (cf. section 4); and similarly for the other corpora. As far as collocations are concerned, it is interesting that each cardinal posture verb does not often occur with the others as part of the conjunctions we investigated in sec- 
tion 5 (see the results in Table 8). Some associates in Table 17 are comparable to the recurring collocate sets we observed in Tables 10 and 15. Thus, sit is associated with a number of words relating to prolonged inactivity and extended duration (still, boredom, rest, wait), as well as words denoting mental activity (think). Stand is associated with words denoting extended duration (still, wait, waiting) and balance (erect, straight). Lie is associated with words suggesting passive states (sleep, die, in bed, rest), comparable to the lay down collocates summarized in Table 15. Despite some overlap between the paradigmatic patterns of word associations in the Edinburgh Associative Thesaurus and the syntagmatic patterns of collocation in the corpora, the patterns are influenced by different factors and one should not expect the results to be anything more than suggestive. Nevertheless, we have found some intriguing matches between the cardinal posture-verb collocates (as shown in the corpus returns) and the cardinal posture-verb associates (as shown in the Edinburgh Associative Thesaurus returns) which, taken together, advance our understanding of the lexicosyntactic behavior of these verbs.

\section{Extensions to inanimate subjects}

We are aware that the English cardinal posture verbs may be used with non-posture-taking inanimate or abstract subjects (e.g., Two candles stand on the altar, That file sat on my desk for a week unnoticed), a type of extension which is found in other languages. The use with inanimate subjects can become so pervasive and entrenched in some languages that one or more of the posture verbs in a language is preferred or obligatory in constructions which serve primarily to locate an entity or refer to its existence. We were interested in exploring the frequency of such extensions to inanimate, non-posture-assuming subjects in the British National Corpus.

The British National Corpus is not semantically tagged in the way parts of the BROWN corpus have been and it is not possible to directly search for an "animate" collocate of a posture verb. The only reliable method of obtaining frequency information about the animacy of the covert or overt subject of a posture verb in the British National Corpus is via line-by-line inspection of some subset of data (as carried out in Newman 2001, discussed further below). In order to reduce the amount of detailed inspection which would be necessary in the case of the British National Corpus, some selection process was needed. We restricted ourselves to search strings of the posture verbs immediately followed by HERE or THERE. These expressions can comfortably refer to stative situations and permit inanimate subjects (e.g., the house stood there for a long time), 
Table 18. Normalized frequency per million words of SIT HERE/THERE, STAND HERE/THERE, LIE HERE/THERE in the British National Corpus (with actual frequencies in parentheses)

\begin{tabular}{llll}
\hline & SIT HERE/THERE & STAND HERE/THERE & LIE HERE/THERE \\
\hline $\begin{array}{l}\text { BNC written } \\
\text { (90 million words) }\end{array}$ & $14.7(1,330)$ & $15.6(1,405)$ & $6.8(614)$ \\
$\begin{array}{l}\text { BNC spoken } \\
(10 \text { million words) }\end{array}$ & $91.8(918)$ & $28.9(289)$ & $3.9(39)$ \\
\hline
\end{tabular}

contrasting in this respect with SIT DOWN, STAND UP, LIE DOWN. Furthermore, the presence of HERE/THERE immediately to the right of the posture verb eliminates many, if not all, of the idiomatic expressions in which the verb is followed by a particle or preposition (stand on ceremony, stand up for one's rights, sit on a matter, etc.). The results obtained from these searches are shown in Table 18. As seen with the SIT DOWN, STAND UP, LIE DOWN searches reported on above, the SIT expression is by far the most common in spoken corpora and the LIE expression is the least common in both written and spoken corpora.

We then sought 100 random examples (utilizing a tool included with the SARA query application provided with the British National Corpus) from each of the cells in Table 18 with more than 100 actual tokens. To these random examples were added all 39 examples of LIE HERE/THERE in the British National Corpus spoken corpora. We then inspected each of the 539 examples to ascertain whether the referent of the (overt or covert) subject of the posture verb was animate or not. The results are summarized in Table 19. For comparison, we cite in Table 20 results from a separate corpus-based study (Newman 2001), investigating the animacy of the "figure" of English sitting, standing, and lying. The corpus used in Newman (2001) was the BRSPOKE subcorpus of the Bank of English, a

Table 19. Percentage of inanimate subjects of posture verbs in random selections (100 random utterances for each expression with more than 100 search results) from the British National Corpus (with actual frequencies in parentheses)

\begin{tabular}{llll}
\hline & SIT HERE/THERE & STAND HERE/THERE & LIE HERE/THERE \\
\hline $\begin{array}{l}\text { BNC written } \\
(90 \text { million words) }\end{array}$ & $2 \%$ & $3 \%$ & $19 \%$ \\
$\begin{array}{l}\text { BNC spoken } \\
(10 \text { million words) }\end{array}$ & $4 \%$ & $2 \%$ & $18 \%$ (7 out of 39) \\
\hline
\end{tabular}


Table 20. Percentage of inanimate figures of sitting, standing, and lying $+\mathrm{PP}$ in the BRSPOKE corpus (with actual frequencies in parentheses)

\begin{tabular}{llll}
\hline & sitting + PP & standing + PP & lying + PP \\
\hline BRSPOKE & $2 \%$ & $2 \%$ & $12 \%$ \\
$(20.2$ million words $)$ & $(13 / 682)$ & $(5 / 241)$ & $(14 / 114)$ \\
\hline
\end{tabular}

subcorpus consisting of 20.2 million words of transcribed contemporary, informal, spoken British English. The search strings in that study were the -ing forms sitting, standing, and lying immediately followed by a prepositional phrase (e.g., she was sitting in the kitchen, I can see someone standing at the counter, she was always lying in bed). These searches yielded over 1,000 hits which were also inspected individually to exclude noun uses (e.g., his standing in society) and irrelevant meanings (the "telling a lie" sense of lying). A "figure", meaning the person, animal, or thing understood as the entity in the sitting, standing, or lying position, was identified for each occurrence of sitting, standing, and lying (sometimes these were syntactic subjects and sometimes not). The figures were then classified into animate versus inanimate categories. The results are shown in Table 20. The percentages obtained through the randomized sampling approach underlying Table 19 and the comprehensive nonrandomized approach underlying Table 20 are quite comparable, lending further support to the adoption of the random-sampling technique. The use of here/ there in the posture expressions might be expected to bias the search towards more deictically charged usages and many of the examples do have first or second-person, i.e., animate subjects. However, the BRSPOKE searches yielded comparable results without any here/there as part of the search string, so the presence of here/there does not seem to unduly affect the animacy of the subject referent.

It can be seen that, relatively speaking, the sit and stand expressions occur less frequently with inanimate subjects than do the lie expressions in both Tables 19 and 20. Although almost negligible in terms of frequency, the SIT HERE/THERE, STAND HERE/THERE examples are nevertheless instructive. All of the examples from this restricted search are given in (15) and (16). Both the logical subject and the posture verb phrases are underlined.

(15) SIT HERE/THERE

a. She looked over at the long table. The six cakes sat there, apparently innocent and, oddly enough, still appetizing. (BNC written) 
b. Straightforward in principle, although highly complex in technical detail, the majority of today's desk-top fax machines rarely seek to sell themselves with seductive design [the usual Japanese route to consumer appeal]; they just sit there, looking like little photocopiers or big telephones, doing what they are supposed to do. (BNC written)

c. ... we've actually got the land for the er the fire station, I think you you were there with us. ... erm, it's actually sitting there on the Meridian er Business Park, it's been sitting there for three years er overgrown with er grass and what have you and it's there. (BNC spoken)

d. I mean we've always got drink in the house and s and occasionally we'll have a drink at night but sometimes we just don't touch it for ages unless anyone comes round. It just sits there ... (BNC spoken)

e. I love cheese and biscuits. It's sort of, if it's gonna sit there, and get nice and warm and Soggy. ... (BNC spoken)

f. And the bus left at a quarter past eight. Hour and a quarter. I could have travelled home. Yeah. Bloody hell. Honestly, it was just sitting there, we were just not moving. (BNC spoken)

(16) STAND HERE/THERE

a. In 1291 a rectory stood here, valued in that year at $£ 1013 \mathrm{~s} 4 d$. (BNC written)

b. There is documentary evidence that a corn mill stood here in 1624, although by 1645 it was used as a blast furnace. (BNC written)

c. And he bustled out on to the landing to fetch a straight-backed chair that stood there for no particular reason. (BNC written)

d. She says well, she says, that garage is in a hell of a mess you know, and that Norton [the Norton Anthology] standing there doing nothing. (BNC spoken)

e. Rob made me a cup of coffee and erm I forgot it had been standing there and er I went to take a mouthful course I got a mouth full of skin didn't I? (BNC spoken)

A striking feature of the SIT HERE/THERE examples in (15) is a nuance, sometimes even an explicit indication, of prolonged inactivity. The presence of just in some of these examples accentuates this idea, as in the case of sitting around and, discussed above. In other cases, temporal phrases like three years, in reference to unused land in (15c), or hour and a quarter, in reference to the bus not moving in (15f), elaborate on an extreme 
temporal extension of the state. In the case of the cakes referred to in (15a), the further reference to innocent also carries a nuance of the cakes simply being there, not doing anything. Indeed, in all these cases with SIT HERE/THERE, the sense of inactivity is a prominent component of the expression's overall meaning. It is also present in the case of two STAND HERE/THERE examples, (16c) and (16d). Another aspect of some SIT examples is the rather figurative style of expression employed. The six cakes in (15a) are described as apparently innocent; the fax machines in (15b) are said to rarely seek to sell themselves. These are ways of describing inanimate objects which are indicative of a familiar narrative style involving personification. In none of these examples, involving a variety of multishaped themes (e.g., cakes, fax machines, land, bus, cheese and biscuits) does the shape of the entity appear to be a very significant factor.

These observations do not apply in the same way to LIE HERE/THERE. Typical examples for these expressions are given in (17). Again, both the logical subject and the posture verb phrase are underlined.

(17) LIE HERE/THERE

a. Despite the prompting of his imagination, it seemed that the key to the mysteries did not lie here after all. (BNC written)

b. ... it was like seeing a real dead body lying there ... (BNC written)

c. The real records now lie there, on my desk. They show quite clearly what happened. (BNC written)

d. He strolled up and down for five minutes then, on the dot of ten, dropped the fat envelope through the letter-box of the apartment-house. There was no hall porter to pick it up. It lay there on the mat inside the door. (BNC written)

e. ... there lies here a nexus of issues to which theologians have had to turn their attention ... (BNC written)

f. Melford pointed to the corpse on the bed and the flower still lying there (BNC written)

With LIE HERE/THERE we find abstract entities such as the key to the mysteries and a nexus of issues serving as subject, as well as contextual references to corpses.

Our methodology allows us to have a sense of the relative prominence of animate versus inanimate subjects with the cardinal posture verbs. It does not present the full picture about the subjects used with these verbs because of the selective nature of the data. However, the random sampling undertaken does give some insight into major versus minor trends in usage. The verbs which are most frequent (SIT, STAND) are the ones which 
show the lightest usage with inanimate subjects, whereas the least frequent verb, LIE, co-occurs most often with inanimate and abstract subjects, as befitting a verb which is associated with the least amount of sensorimotor control and sentience. All three cardinal posture verbs can obviously be used with inanimate subjects, but the basis for the extension is different: SIT, more so than STAND and LIE, is extended to indicate a relatively long period of inactivity. Indeed, this appears to be the most common basis for the use of SIT with inanimate subjects. An interesting comparison can be made with the use of posture verbs in Manam, as reported by Lichtenberk (2002). The Manam human posture verbs tui 'stand', soa?i 'sit', and eno 'lie' all have additional uses referring to the location or existence of inanimate entities, though the extent to which they do so differs for all three. The "stand" verb is extended to inanimates (or animates) whose referents have a long vertical extension (or can be so construed); the "sit" verb is a semantically unmarked locational or existential predicate for boats on water; the "lie" verb functions as the default locational or existential predicate for all other inanimates, i.e., used except when a long vertical extension demands the "stand" verb or when "sit" is required for boats on water. Thus, in Manam, there is a strong association between the use of the "lie" verb with inanimate subject entities to the point that it is virtually the unmarked locational or existential predicate with inanimates. In English, all three cardinal posture verbs can be used with inanimate subjects (cf. examples [15] to [17]), with LIE favoring such subjects to a greater degree than SIT or STAND. ${ }^{11}$ What is revealed as a tendency in the British National Corpus corpus, therefore, corresponds to a more categorial use of the "lie" verb as the unmarked locational or existential predicate with inanimates in Manam. ${ }^{12}$

Our findings relating to animacy of subject referents with English cardinal posture verbs are summarized in Table 21.

\section{Conclusion}

Our study has revealed some striking patterns of usage with the English cardinal posture verbs, suggestive of how corresponding verbs in other languages have extended functionally, although the English verbs have yet to undergo full-blown grammaticalization. These patterns, though consonant perhaps with our intuitions about implicatures associated with the cardinal posture verbs, are best substantiated through the methodology of corpus linguistics. We examined both lemma frequencies of these verbs in isolation as well as in a host of multi-verb constructions containing these verbs. Not surprisingly, given our cognitive linguistic biases 
Table 21. Attributes associated with the English cardinal posture verbs with inanimate subjects in the British National Corpus

\begin{tabular}{ll}
\hline CPV collocation & Properties and associations \\
\hline SIT HERE/THERE & $\begin{array}{l}\text { shows very limited use with INANIMATE SUBJECTS } \\
\text { suggests PROLONGED INACTIVITY } \\
\text { sTAND HERE/THERE }\end{array}$ \\
& shows very limited use with INANIMATE SUBJECTS \\
& weakly suggests VERTICAL EXTENSION of subject \\
LIE HERE/THERE & shows more extensive use with INANIMATE SUBJECTS, \\
& especially those having a perceived HORIZONTAL ORIENTATION \\
& is used with ABSTRACT SUBJECTS \\
& is used with TIME-STABLE SUBJECTS \\
& suggests EXISTENCE \\
\hline
\end{tabular}

which hold that, above all, language is embodied, the verb collocates of posture verbs in conjoined expressions reflect the experiential realities associated with the role of sitting, standing, and lying in our daily lives in quite a revealing and measurable way. The corpora have thrown up an interesting set of results to contemplate: the cardinal posture verbs are distinguished from other posture verbs in their relative frequency; within the set of cardinal posture verbs, the relative frequencies of the verbs (ignoring context) in multiple corpora are consistently SIT > STAND > LIE; in simultaneous conjunction, each cardinal posture verb patterns with a distinctive set of collocates, with sitting exhibiting the largest and most diverse set of collocates; in consecutive conjunction, different patterns of collocation occur, with stood having the largest and most diverse set of collocates.

While corpus-based studies of a language are valuable in terms of adding to our knowledge of the actual usage patterns of that language, the particular study we have carried out goes beyond this goal and illuminates more general questions about language and language change that are of interest to cognitive linguists and grammaticalization scholars. The usage frequencies garnered from our various contextualized searches have enabled us to link observed patterns in English to grammaticalization tendencies known about cardinal posture verbs in other languages. We believe that the frequencies of usage that we have found for the English cardinal posture-verb lemmas in section 3 are relatable to grammaticalizations affecting the counterparts of these same three verbs in other languages. The relative frequencies of the cardinal posture verbs with respect to one another (section 4) may also be relevant to the differing extent to 
which each of the three appears to participate in grammaticalization processes. The collocational patterns of the cardinal posture verbs occurring in simultaneous and consecutive conjunction (section 5) are relatable to a number of auxiliation grammaticalizations, such as those listed in (4). Both types of conjunction prove relevant in this regard. The simultaneous conjunction patterns reveal patterns of prolonged human inactivity, relatable to grammaticalizations associated with an extension through time (e.g., progressive, durative, continuative, persistive aspect); the consecutive conjunction reveals the uniqueness of stood up as a verb form associated with further human movement and activity, correlating with the grammaticalizations of "stand" (but not "sit" or "lie") as inchoative verbs or other markers of subsequent action. The British National Corpus (and other large corpora) provide us with a sizeable body of data to establish features of usage such as the animacy of the subject phrase of a posture verb or the understood figure in the figure-ground relationship implied by a posture verb and prepositional phrase. In the corpora we utilized, animacy was a far more dominant feature of usage of cardinal posture verbs than one might expect from, say, consulting a dictionary or even from introspection.

A corpus-based approach, in particular using a corpus of the magnitude of the British National Corpus, allows a more fine-grained study of the cardinal posture verbs' embedded usage and function than could be gained from introspective analysis alone. Nevertheless, a comparison of our own corpus-based results with the empirically based Edinburgh Associative Thesaurus results on word associations revealed interesting similarities. SIT and STAND (but not LIE) readily associate with each other in the Edinburgh Associative Thesaurus, comparable to the way in which the cardinal posture verbs pattern as a set, as discussed in section 3. LIE is always the least frequent of the three posture verbs. Furthermore, there is overlap between the associate sets of the cardinal posture verbs, as found in the Edinburgh Associative Thesaurus, and the collocate sets of the cardinal posture verbs, as found in section 5. The patterns in the external data (the corpora) thus lend further substantiation to the patterns arising out of introspective inquiry (data from the Edinburgh Associative Thesaurus as well as linguists' intuitions). At best, the latter can only tell us where the grammar has been. However, the corpus data make this case in an empirically verifiable, objective, and testable way. This methodology, more than any other, lets the data speak for themselves, giving us broad hints about where the grammar may be going. 


\section{Appendix: SIT/STAND/LIE around and occurrences in the British National Corpus}

(i) SIT around and ... V (31 occurrences)

... if we can sit around and actually make some work of cards ...

Sit around and be depressed?

... instead of sitting round and bitching about them, which you can do, it's better to try to take more of an interest and make interesting videos,....

You surely don't think I plan just to sit around and do nothing about getting my speedboat back, not to mention my cousin?

I think that anybody who sits around and doesn't make the investment has got big problems coming in the future.

I enjoy talking about things other than golf, I love just sitting around and doing nothing, watching $T V$, going into the kitchen, walking around $a$ while and watching the stock market.

It's so full of happy memories for me, and I would hate to sit around and grow old, and let them all turn stale.

The inspector drew attention to the absence of dayrooms for the ambulant chronic sick, who sat around and had their meals in the wards, where "there were very few wooden armchairs".

... the sort of meal for intimate friends when you can put all the food on a huge scrubbed kitchen table and everyone sits round and helps themselves.

Jim wasn't the sort to sit around and let someone else fight his war.

I don't have time to waste sitting around and letting you practise your minimal talents on me.

I could sit around and listen to that smoky voice all day.

What the shift over the last twelve months confirms is this: there's no point in sitting around and moaning.

Sit around and pray for a miracle?

But now everybody does it and I'm not going to sit around and say, "Oh yeah, well that was my shit and everybody copied my sound."

Perhaps he can just sit around and score.

I hate it when we sit around and sit around.

A paint party, we can all sit around and sniff paint.

... you will probably want to make it much more of a family room where people can sit around and talk, have a drink, do their homework, write notes, lists, letters, pay bills, and do a lot of eating.

She did, however, enjoy the people sitting around and talking, the sociable atmosphere ...

After I talked to Mr. Connors here, I sat around and thought it all over. 
Christmas Eve, when the Victorians sat round and told ghost stories.

I think Martin was tired of sitting round and vomiting.

Sit around and wait for a gridlock, hoping it falls before the next General Election?

Yet actors here think they can just sit around and wait for jobs.

Do you just sit around and wait for inspiration?

My plan was to sit around and wait for one of the parish team to appear and then to ask them for their advice.

And did they, they must have had lean times if they sat around and waited for a boat, one didn't come in some days may be.

... and then afterwards we sat around and were asked who would volunteer to stand up and read their piece.

So you have your group sitting round and you say, this is our problem now that we're going to actually home in on.

... you, you sit round and you tell them that they can say anything they like, no holds barred, and nobody's going to criticise anything they say.

(ii) STAND around and ... V (9 occurrences)

"There's no point having them standing around and eating the provisions."

They all stood around and hated Skull.

He recalled how as a five-year-old he had ridden on the back of a huge sow, beating it with a twig as the men stood around and laughed and the women sharpened the knives.

They all stood around and listened.

You will stand around and look at me, you here, you there, you next to her, you two there.

Once you've been going to the same shops a lot, y'know, just standing around and not buying anything, they get to know you.

... the concept of putting a little circle down and one word in it and expanding that out and being able to stand around and talk erm for three minutes or ten minutes or whatever for a significant amount of time erm that that was also a revelation to me.

When we had association we'd stand around and talk, or sit and watch telly or have a bath and wash our hair.

We'd been practising hard and were having a rest, just standing around and the Head Girl was smoking.

Two men were dancing, or rather standing around and twitching a little as the two boys danced around them, brilliantly, Harry noted.

(iii) LIE around and ... V (8 occurrences)

... so I just picked up a pair of scissors that were lying around and cut off a lock of her hair. 
Everyone else was lying around and I just thought: "That's it, I've had enough".

"There are unexploded shells lying around and live firing takes place there."

"We took prints we had lying around and played with them and all of a sudden that broke everything loose".

... where he could leave his things lying around and put his feet on the table?

Lopped off brambles lay around and the long grass was all trampled.

They'd left the plates lying around and the wine bottles on the floor, and there was still a bit of wine left in one of them.

There was a dark place-some boat fitter's equipment was lying around and there was the sailmaker's van as well as parked cars.

\section{Notes}

* An earlier version of this paper was presented at the 2001 International Cognitive Linguistics Conference at the University of California, Santa Barbara and we are grateful for feedback from that audience. We would also like to thank two anonymous Cognitive Linguistics reviewers for their helpful comments and suggestions. John Newman is grateful to the Massey University Research Fund (1.0510.53148.MURF) for financial support for part of this research. The authors can be contacted at the Department of Linguistics, University of Alberta, Edmonton, Alberta, T6G 2E7 Canada. E-mail: 〈john.newman@ualberta.ca〉,〈sally.rice@ualberta.ca〉.

1. We use small caps (e.g., SIT) to refer to both a concept and a lemma (including all its inflected forms) and italics (e.g., sit) to refer to a particular form of a word.

2. By no means are posture verbs special in this regard. Basic verbs (those relating to everyday human activity) are notorious for grammaticalizing into markers of tense, aspect, and mood cross-linguistically. Basic verbs include lemmas like COME, GO, TAKE, SAY, SEE, WANT, and GIVE. This study focuses on a special subset of basic verbs, the cardinal posture verbs.

3. See, for example, Bybee 1985: 72; Bybee and Hopper 2001; Bybee et al. 1994: 4-9; Heine et al. 1993: 17; Hopper and Traugott 1993: 59-160, 101-114, 142-145; Ramat and Hopper 1998.

4. A very specific attempt to investigate the psychological realities underlying the polysemy of English STAND in certain figurative usages was carried out by Gibbs, Beitel, Harrington, and Sanders (1994).

5. Note that in this listing SIT appears to be the most prolific cardinal posture verb in terms of its heterosemy or functional extendedness.

6. $\neq$ in (a) is a nasalized alveolar click; // is a lateral click.

7. See de Beaugrande (1996) for a discussion of the qualitative difference between smaller corpora like the BROWN corpus and large corpora like the British National Corpus. Also see Newman and Rice (2001) for some discussion of the consistency and reliability of search results on English posture verbs in smaller and larger corpora.

8. Hopper's observation is about the persistence of lexical meaning at the end-stage of the grammaticalization process. By contrast, we are examing lexical meaning in detail and looking for signs of incipient grammaticalization. 
9. _ as in $k a \_i n$ is used by Guirardello-Damian (2002: 175) to refer to "morphemes which are independent, but generally associated in a specific context."

10. The Edinburgh Associative Thesaurus is available on-line at http://monkey.cis.rl.ac.uk/ Eat/htdocs/eat.html.

11. As an anonymous reviewer helpfully pointed out, all the LIE examples in (17) happen to involve figures which can be regarded as essentially flat or extending in the horizontal plane, viz. a key, a dead body, an envelope, flowers on a corpse, etc. The same could be said for the figures in the lie around and constructions given in the Appendix: a pair of scissors, a bullet shell, photographs, plates, etc. Clearly, canonical shape or orientation of the figure is still playing a role in English when LIE is being used as an existential or locative, unlike its use in Manam where shape or orientation is virtually irrelevant.

12. Another point of similarity between English and Manam concerns the use of the "lie" verb with abstract entities. Abstract entities show up with LIE in our random samples in the British National Corpus, but not with SIT or STAND. Although abstract entities are possible as subjects of SIT and STAND (e.g., as the matter stands ...), such uses did not occur in our random sampling. In Manam, according to Lichtenberk (2002), only the "lie" verb is used as the existential verb with abstract subject referents. This Manam categorial rule corresponds to an English tendency.

\section{References}

Austin, Peter

1998 "Crow is sitting chasing them": Grammaticization and the verb "to sit" in the Mantharta languages, Western Australia. In Siewierska, Anna and Jae Jung Song (eds.), Case, Typology and Grammar. Amsterdam/Philadelphia: John Benjamins, 19-35.

Barlow, Michael and Suzanne Kemmer (eds.) $2000 \quad$ Usage-Based Models of Language. Stanford: CSLI Publications.

Buck, Carl Darling

1949 A Dictionary of Selected Synonyms in the Principal Indo-European Languages. Chicago/London: University of Chicago Press.

Bybee, Joan L.

1985 Cross-linguistic comparison and the development of grammatical meaning.

In Fisiak, Jacek (ed.), Historical Semantics, Historical Word Formation.

Berlin/New York: Mouton de Gruyter, 59-83.

Bybee, Joan L., Revere Perkins, and William Pagliuca

1994 The Evolution of Grammar: Tense, Aspect and Modality. Chicago: Chicago University Press.

Bybee, Joan L. and Paul J. Hopper (eds.)

2001 Frequency and the Emergence of Linguistic Structure. Amsterdam/Philadelphia: John Benjamins.

Comrie, Bernard

1976 Aspect. Cambridge: Cambridge University Press.

de Beaugrande, Robert

1996 The "pragmatics" of doing language science: The "warrant" for largecorpus linguistics. Journal of Pragmatics 25, 503-535.

Deane, Paul

2002 Zipf's law and the analogical induction of lexical properties. Paper presented at 6th Conference on Conceptual Structure, Discourse and Language (CSDL 2002), Rice University, October 11-14. 
Devoto, Giacomo and Gian Carlo Oli

1971 Dizionario della Lingua Italiana. Florence: Le Monnier.

Early, Robert

1995 Sit, stand, lie: Posture verbs and imperfectives. Paper presented at the Second International Conference on Oceanic Linguistics, Suva.

Fellbaum, Christiane (ed.)

1998 WordNet: An Electronic Lexical Database. Cambridge, MA: MIT Press.

Gardiner, Alan H.

1957 Egyptian Grammar: Being an Introduction to the Study of Hieroglyphs. 3rd ed. Oxford: Oxford University Press.

Gibbs, Raymond W., Jr., Dinara A. Beitel, Michael Harrington, and Paul E. Sanders

1994 Taking a stand on the meanings of Stand: Bodily experience as motivation for polysemy. Journal of Semantics 11, 231-251.

Gries, Stefan Th. and Anatol Stefanowitsch

2002 Collostructions: On the interaction between verbs and constructions. Paper presented at 6th Conference on Conceptual Structure, Discourse and Lan-

Guirardello, Raquel guage (CSDL 2002), Rice University, October 11-14.

1999 A reference grammar of Trumai. Unpublished Ph.D. thesis, Rice University. Guirardello-Damian, Raquel

2002 The syntax and semantics of posture verbs in Trumai. In Newman, John (ed.), 141-177.

Heine, Bernd

1994 Grammaticalization as an explanatory parameter. In Pagliuca, William (ed.), Perspectives on Grammaticalization. Amsterdam/Philadelphia: John Benjamins, 255-287.

Heine, Bernd, Ulrike Claudi, and Friederike Hünnemeyer

1991 Grammaticalization: A Conceptual Framework. Chicago/London: University of Chicago Press.

Heine, Bernd, Tom Güldemann, Christa Kilian-Hatz, Donald A. Lessau, Heinz Roberg, Mathias Schladt, and Thomas Stolz

1993 Conceptual Shift: A Lexicon of Grammaticalization Processes in African

Hopper, Paul J.

Languages. Cologne: Institut für Afrikanistik, University of Cologne.

1991 On some principles of grammaticalization. In Traugott, Elizabeth Closs and

Bernd Heine (eds.), Approaches to Grammaticalization, vol. 1: Focus on Theoretical and Methodological Issues. Amsterdam/Philadelphia: John Benjamins, 17-35.

Hopper, Paul J. and Elizabeth Closs Traugott

1993 Grammaticalization. Cambridge: Cambridge University Press.

Keegan, John M.

1997 A Reference Grammar of Mbay. Munich/Newcastle: Lincom Europa.

2002 Posture verbs in Mbay. In Newman, John (ed.), 333-358.

Kiss, G. R., C. Armstrong, R. Milroy, and J. Piper

1973 An associative thesaurus of English and its computer analysis. In Aitken,

Adam Jack, Richard Weld Bailey, and Neil Hamilton-Smith (eds.), The

Köhler, Oswin

Computer and Literary Studies. Edinburgh: University Press, 153-165.

1962 Studien zum Genussystem und Verbalaufbau der zentralen KhoisanSprachen. Anthropos 57, 529-546. 
1981 La langue kxoe. In Manessy, Gabriel (ed.), Les Langues de l'Afrique Subsaharienne. Paris: Editions du Centre National de la Recherche Scientifique, $485-555$.

Koops, Christian

2001 Emergent progressive aspect constructions: A study of present-day English from a cross-linguistic perspective. Unpublished MA thesis, Hamburg University.

in press Motivating the rise of grammar: Evidence from emergent aspect constructions. In Panther, K.-U. and G. Radden, Motivation in Grammar, Berlin/

Kuteva, Tania A. New York: Mouton de Gruyter.

1999 On "sit"/"stand"/"lie" auxiliation. Linguistics 37, 191-213.

Langacker, Ronald W.

1987 Foundations of Cognitive Grammar, vol. 2. Stanford: Stanford University Press.

1988 A usage-based model. In Rydzka-Ostyn, Brygida (ed.), Topics in Cognitive Linguistics. Amsterdam/Philadelphia: John Benjamins, 127-161.

1997 The contextual basis of cognitive semantics. In Nuyts, Jan and Eric Pedersen (eds.), Language and Conceptualization. Cambridge: Cambridge University Press, 229-252.

Lichtenberk, Frantisek

2002 Posture verbs in Oceanic. In Newman, John (ed.), 269-314.

Linn, Mary

2000 A Grammar of Euchee (Yuchi). Unpublished Ph.D. dissertation, University of Kansas.

Newman, John

2001 A corpus-based study of the figure and ground in sitting, standing, and lying constructions. Studia Anglica Posnaniensia 36, 203-216.

2002a A cross-linguistic overview of the posture verbs "sit", "stand", and "lie". In Newman, John (ed.), 1-24.

Newman, John (ed.)

2002b The Linguistics of Sitting, Standing, and Lying. Amsterdam/Philadelphia: John Benjamins.

Newman, John and Sally Rice

2001 English SIT, STAND, and LIE in small and large corpora. The ICAME Journal $25,109-133$.

Newman, Paul and Russell G. Schuh

1974 The Hausa aspect system. Afroasiatic Linguistics 1, 1-39.

Ogden, Charles K.

1934 The System of Basic English. New York: Harcourt, Brace, and Company.

Palermo, David S. and James J. Jenkins

1964 Word Association Norms: Grade School through College. Minneapolis: University of Minnesota Press.

Ramat, A. G. and P. J. Hopper (eds.)

1998 The Limits of Grammaticalization. Amsterdam/Philadelphia: John Benjamins.

Rice, Sally

1996 Prepositional prototypes. In Dirven, René and Martin Pütz (eds.), The Construal of Space in Language and Thought. Amsterdam/Philadelphia: John Benjamins, 135-165. 
1999 Patterns of acquisition in the emerging mental lexicon: The case of "to" and "for" in English. Brain and Language 68, 268-276.

Rice, Sally and John Newman

2002 Aspect in the making: Aspectualization of English prepositions. Paper presented at 6th Conference on Conceptual Structure, Discourse and Language (CSDL 2002), Rice University, October 11-14.

Sandra, Dominiek and Sally Rice

1995 Network analyses of prepositional meaning: Mirroring whose mind-the linguist's or the language user's? Cognitive Linguistics 6, 89-130.

Schönefeld, Doris

1999 Corpus linguistics and cognitivism. International Journal of Corpus Linguistics $4,137-171$.

Schützeichel, Rudolf

1969 Althochdeutsches Wörterbuch. Tübingen: Niemeyer.

Serra Borneto, Carlo

1996 Liegen and stehen in German: A study in horizontality and verticality. In Casad, Eugene H. (ed.), Cognitive Linguistics in the Redwoods: The Expansion of a New Paradigm in Linguistics. Berlin/New York: Mouton de Gruyter, 459-505.

Thorndike, Robert and Irving Lorge

$1954 \quad$ Lorge-Thorndike Intelligence Tests. Boston: Houghton-Mifflin.

van Oosten, Jeanne

1982 Sitting, standing, and lying in Dutch: A cognitive approach to the distribution of the verbs zitten, staan, and liggen. In van Oosten, Jeanne and Johan P. Snapper (eds.), Dutch Linguistics at Berkeley. Berkeley: Dutch Studies Vorbichler, Anton Program, University of California at Berkeley, 137-160.

1971 Die Sprache der Mamvu. Glückstadt: J. J. Augustin.

Wagner, G.

1933-1938 Yuchi. Bureau of American Ethnology, B 40.3: 293-384.

Watkins, Laurel J.

1976 Position in grammar: Sit, stand, lie. Kansas Working Papers in Linguistics 1, $16-41$.

Zipf, George Kingsley

1932 Selected Studies of the Principle of Relative Frequency in Language. Cambridge, MA: Harvard University Press. 